\title{
Article \\ Differences in Ionic, Enzymatic, and Photosynthetic Features Characterize Distinct Salt Tolerance in Eucalyptus Species
}

\author{
Hazar Balti ${ }^{1,2,3}$, Mejda Abassi ${ }^{3}\left(\mathbb{D}\right.$, Karl-Josef Dietz ${ }^{2, *(\mathbb{D})}$ and Vijay Kumar ${ }^{2}$ (D) \\ 1 Faculty of Sciences of Tunis, University of Tunis El Manar, Tunis 2092, Tunisia; balti_hazar@yahoo.com \\ 2 Department of Biochemistry and Physiology of Plants, Faculty of Biology, University of Bielefeld, \\ 33615 Bielefeld, Germany; vijay.kumar@uni-bielefeld.de \\ 3 Laboratory of Forest Ecology, National Research Institute of Rural Engineering, Water and Forests, \\ Street Hedi Elkarray, Elmenzah IV, BP 10, Ariana 2080, Tunisia; mej_abassi@yahoo.fr \\ * Correspondence: karl-josef.dietz@uni-bielefeld.de
}

check for

updates

Citation: Balti, H.; Abassi, M.; Dietz, K.-J.; Kumar, V. Differences in Ionic, Enzymatic, and Photosynthetic Features Characterize Distinct Salt Tolerance in Eucalyptus Species. Plants 2021, 10, 1401. https:// doi.org/10.3390/plants10071401

\section{Academic Editors:}

Enrique Troyo-Diéguez and

Pablo Preciado-Rangel

Received: 27 May 2021

Accepted: 6 July 2021

Published: 9 July 2021

Publisher's Note: MDPI stays neutral with regard to jurisdictional claims in published maps and institutional affiliations.

Copyright: (C) 2021 by the authors. Licensee MDPI, Basel, Switzerland. This article is an open access article distributed under the terms and conditions of the Creative Commons Attribution (CC BY) license (https:// creativecommons.org/licenses/by/ $4.0 /)$.

\begin{abstract}
In the face of rising salinity along coastal regions and in irrigated areas, molecular breeding of tolerant crops and reforestation of exposed areas using tolerant woody species is a two-way strategy. Thus, identification of tolerant plants and of existing tolerance mechanisms are of immense value. In the present study, three Eucalyptus ecotypes with potentially differential salt sensitivity were compared. Soil-grown Eucalyptus plants were exposed to 80 and $170 \mathrm{mM} \mathrm{NaCl}$ for 30 days. Besides analysing salt effects on ionic/osmotic balance, and hydrolytic enzymes, plants were compared for dynamics of light-induced redox changes in photosynthetic electron transport chain (pETC) components, namely plastocyanin (PC), photosystem I (PSI) and ferredoxin (Fd), parallel to traditional chlorophyll a fluorescence-based PSII-related parameters. Deconvoluted signals for PC and Fd from PSI allowed identification of PC and PSI as the prime salinity-sensitive components of pETC in tested Eucalyptus species. Eucalyptus loxophleba portrayed efficient $\mathrm{K}^{+}-\mathrm{Na}^{+}$balance $\left(60-90 \%\right.$ increased $\left.\mathrm{K}^{+}\right)$ along with a more dynamic range of redox changes for pETC components in old leaves. Young leaves in Eucalyptus loxophleba showed robust endomembrane homeostasis, as underlined by an increased response of hydrolytic enzymes at lower salt concentration ( 1.7-2.6-fold increase). Findings are discussed in context of salinity dose dependence among different Eucalyptus species.
\end{abstract}

Keywords: Eucalyptus; salinity; photosynthesis; photosystem II; photosystem I; plastocyanin; ferredoxin; redox; osmotic balance; hydrolases

\section{Introduction}

Soil salinity describes the accumulation of soluble inorganic cations such as $\mathrm{Na}^{+}, \mathrm{Mg}^{2+}$ and $\mathrm{Ca}^{2+}$, together with anions in the form of chloride, carbonate, or sulfate [1]. In fact, excessive use of ion-rich irrigation water causes soil salinization, and this effect is particularly severe in arid and semi-arid regions. Salinity is a major form of abiotic stress that affects plant growth, development, and agriculture productivity worldwide [2,3]. Current estimates suggests that $>6 \%$ of the world's land and $>30 \%$ of all irrigated areas are already suffering from exposure to salinity [4]. In addition to crop yield losses, salinity-dependent vegetation loss has other severe negative impacts on the local ecosystem, such as the removal of natural $\mathrm{CO}_{2}$ sinks with adverse consequences on climate change, soil erosion, poor water retention, etc. These impacts further accentuate drought and salinity effects [5-8]. Reforestation has been a strategy used to counter such self-reinforcing processes. Fastgrowing and salinity-tolerant tree species have shown potential to provide soil stabilization with wood production and could be a long-term solution to restore vegetation in marginal areas and sites affected by salinity [9-12]. For example, Eucalyptus, a multipurpose woody species that develops an extended deep root system, is suitable for many landscape applications including reclamation of dry arid saline lands. In fact, the area under Eucalyptus cultivation has increased 30 times in roughly 60 years, especially in tropical and subtropical 
countries [13]. Many Eucalyptus species like E. sargentii, E. camaldulensis, E. loxophleba, E. spathulate, E. agrophloia and E. neglecta show capacity to tolerate salinity [14-16] and have been used widely to explore salinity tolerance mechanisms in plants.

Salinization leads to reduced soil fertility and decreased water availability [3]. Therefore, along with the accumulation of cytotoxic ions, nutritional imbalance and osmotic and oxidative stresses are major challenges for plants facing salinity [3,17]. Plants use many complementary strategies to counter the negative effects of salt stress [18]. Accumulation of $\mathrm{Na}^{+}$and $\mathrm{Cl}^{-}$ions in the cytosol, stroma, and matrix, the so-called "plasmatic compartments" of the cell, has a chaotropic effect on structure and function of cell membranes and proteins $[17,19]$. Therefore, ion compartmentation by deposition in the vacuole, often of certain cell types like trichomes, epidermis and bladder cells, allow for the lowering of ion concentrations in the plasmatic compartments [17,20,21]. Inadequate compartmentation causes ion accumulation in plasmatic compartments and consequently the loss of membrane integrity, inhibition of activities of different metabolic enzymes and altered cell signaling.

The exclusion of detrimental ions from the cytoplasm is realized by strict regulation of transport processes and synthesis of compatible solutes [20,22,23]. Overall, ion homeostasis is a delicate interaction between inter-organ, organ, inter-cellular and subcellular transport processes [24]. For vacuolar transport and subsequent osmotic homeostasis, ion $/ \mathrm{H}^{+}$-antiporter, vacuolar $\mathrm{Cl}$ - channels and tonoplast intrinsic proteins have been implicated $[17,24,25]$. Despite widely emphasized involvement of vacuoles in ion homeostasis under salinity, the regulation and effects of the accumulated ions on the crucial proteolytic hydrolases, phosphatases or phosphoesterases have not been addressed [17,21]. It is important to note that the regulation of ion accumulation in different compartments depends on factors like total external ion concentrations, effective osmotic homeostasis mechanisms, prevalence of counter-anions like $\mathrm{K}^{+}$, or $\mathrm{Ca}^{2+}$ transport etc. [17,24]. For example, $\mathrm{K}^{+}$concentrations need to be kept high for proper enzyme function and translation, while sodium inhibits these processes [26,27]. For this reason, maintenance of a high potassium-to-sodium ratio under salinity in plasmatic compartments of plant tissues, despite being energy intensive, is crucial for proper activities of several enzymes and membrane functions $[17,22,28]$.

Salinity effects on plant growth can be partially linked to inhibited photosynthesis. Effects of salt exposure on photosynthesis are realized in two stages, where the early osmotic shock and later ion accumulation are responsible for widely observed negative interferences with yield [20]. Perturbed water uptake due to reduced soil water potential leads to osmotic stress, which in turn affects transpiration, stomatal function, and gaseous exchange, thus reducing internal $\mathrm{CO}_{2}$ levels [20]. These changes influence regulation of RuBisCO activity resulting in inhibited carbon assimilation [29,30]. Ionic imbalance, on the other hand, majorly affects optimal protein function in the photosynthetic electron transport chain (pETC), the light dependent photosystem II (PSII; $\mathrm{P}_{680}$ ) damage-repair cycle, and the efficient generation of redox metabolites and excessive generation of reactive oxygen species (ROS); hence, the result is oxidative stress [20,29,31]. Several studies have reported, e.g., inhibition of effective photochemical yield (ФPSII), PSII activity, electron transport rate (ETR), photochemical quenching $\left(\mathrm{F}_{\mathrm{v}} / \mathrm{F}_{\mathrm{m}}, \mathrm{qP}\right)$, and $\mathrm{CO}_{2}$ assimilation upon exposure to salinity $[2,20,32,33]$. In successful acclimation to salinity stress, the optimal control of activity of ROS-generating enzymes like plasma membrane-situated NADPH oxidases $(\mathrm{RBOH})$, mitochondrial alternate oxidase (AOX), and plastid terminal oxidase (PTOX) along with ROS scavenging enzymes like superoxide dismutase, catalase, or several types of peroxidases have been considered essential [33,34].

PSII efficiency has been long correlated to carbon assimilation under abiotic stresses in general, or specifically under salinity. However, the interrelationship between regulation of stress acclimation and the effects of stresses on the efficiency of other components in pETC remain largely unexplored, which is focus of this study. As described above, studied salinity effects on photosynthesis have been mostly observed on parameters related to 
activity, the damage repair cycle of PSII, and, to some extent, on net carbon assimilation rates [21]. On the other hand, redox changes, activity, reaction efficiency and changes in relative pool size of other pETC components on the acceptor and donor sides of PSI ( $\left.\mathrm{P}_{700}\right)$ like plastocyanin (PC) and ferredoxin (Fd) have not been analysed before. One significant reason for this was unavailability of specific, non-invasive analytical methods that could distinguish light absorption/fluorescence characteristics of components like PC, PSI and Fd $[35,36]$. The recently developed kinetic LED array spectrophotometer (DUAL-KLASNIR, Walz, Germany) allows such deconvolution to quantify light-induced redox changes in PC, PSI, and Fd in intact leaves [35-37]. Besides being rapid and highly accurate, these non-invasive procedures facilitate comparisons of stress effects among plants with different leaf morphology, as the quantification is not impaired due to, e.g., different chlorophyll contents or stomatal density. Another major advantage here is that a parallel measurement for chlorophyll a fluorescence is also possible, which allows comparison of stress effects among different pETC components (PSII and PSI) as has been already illustrated in several recent studies for diverse abiotic stresses [38-42].

Thus, in the current study three Eucalyptus species were selected to analyze their salt stress response. The specific objective was to identify overlapping and adaptive changes based on traditional features such as growth, osmotic relations, ion accumulation and oxidative stress. These data were complemented by non-invasive and parallel measurements of efficiency and redox shifts for the pETC components PSII, PC, PSI and Fd. The results underline the inter-relationship between the measured parameters for salt stress acclimation through differential effects among salt-tolerant and -sensitive species and suggests utility and applicability of these non-invasive measurements in salt tolerance assessment.

\section{Results}

\subsection{Plant Morphology and Biomass Production}

The selection of plants to be analysed in the current study was based on the known salt tolerance versus sensitivity of Eucalyptus species. However, to account for differences in salt tolerance that could exist for ecotypes, we also considered the outcome of a preliminary screen of germination and seedling growth involving six Eucalyptus species growing in forests in Tunisia.

This screening assessed the responses of E. gomphocephala A. Cunn. ex DC., E. sargentii Maiden, E. loxophleba Benth., E. gillii Maiden, E. torquata Luehm., and E. gracilis F. Muell. (Supplementary Materials Tables S1 and S2). Thus, during early seedling stages selected species E. loxophleba and E. gomphocephala showed similar tolerance to $\mathrm{NaCl}(0-210 \mathrm{mM}$ $\mathrm{NaCl}$ ), while E. torquata appeared salt-sensitive even at lower salt concentrations (Supplementary Materials Tables S1 and S2). The results of the germination study prompted us to select a moderate $(80 \mathrm{mM})$ and high $(170 \mathrm{mM})$ salt exposure in adult plants for the main experiment.

In general, growth comparison for these three Eucalyptus species in terms of total biomass accumulation under optimal growth conditions for a year revealed highest growth rates for E. torquata (Et) (Supplementary Materials Figure S1). In 6-month-old and subsequently $30 \mathrm{~d}$ salt $(170 \mathrm{mM})$-exposed plants, leaves of $E$. torquata developed necrotic spots that were not so prominent in the other two species. Further, E. gomphocephala (Eg) leaves also showed substantial leaf curling, which was much less in E. loxophleba (El) (Figure 1A). No visible differences were observed in leaf phonotype for all three species at the lower salt concentration of $80 \mathrm{mM}$. Chlorophyll and carotenoids contents showed a similar pattern with a significant decline for both in E. torquata leaves after prolonged salt exposure (Supplementary Materials Figure S2A-D).

Further analysis revealed differences in salt stress effects also on leaf elongation in tested Eucalyptus species (Figure 1B,C). Significant reduction in leaf elongation rate was observed for E. loxophleba (41 and $53 \%$ at 80 and $170 \mathrm{mM} \mathrm{NaCl}$, respectively), and E. torquata ( $45 \%$ at $170 \mathrm{mM}$ ), while the decrease was minimal in E. gomphocephala (Figure 1C). Notably, the total rate of leaf elongation was higher for E. torquata, like the biomass accumulation, 
even after $30 \mathrm{~d}$ salt exposure. This was also the case for plant growth rates for both 7-month and 13-month-old plants (Figure 2A-D).
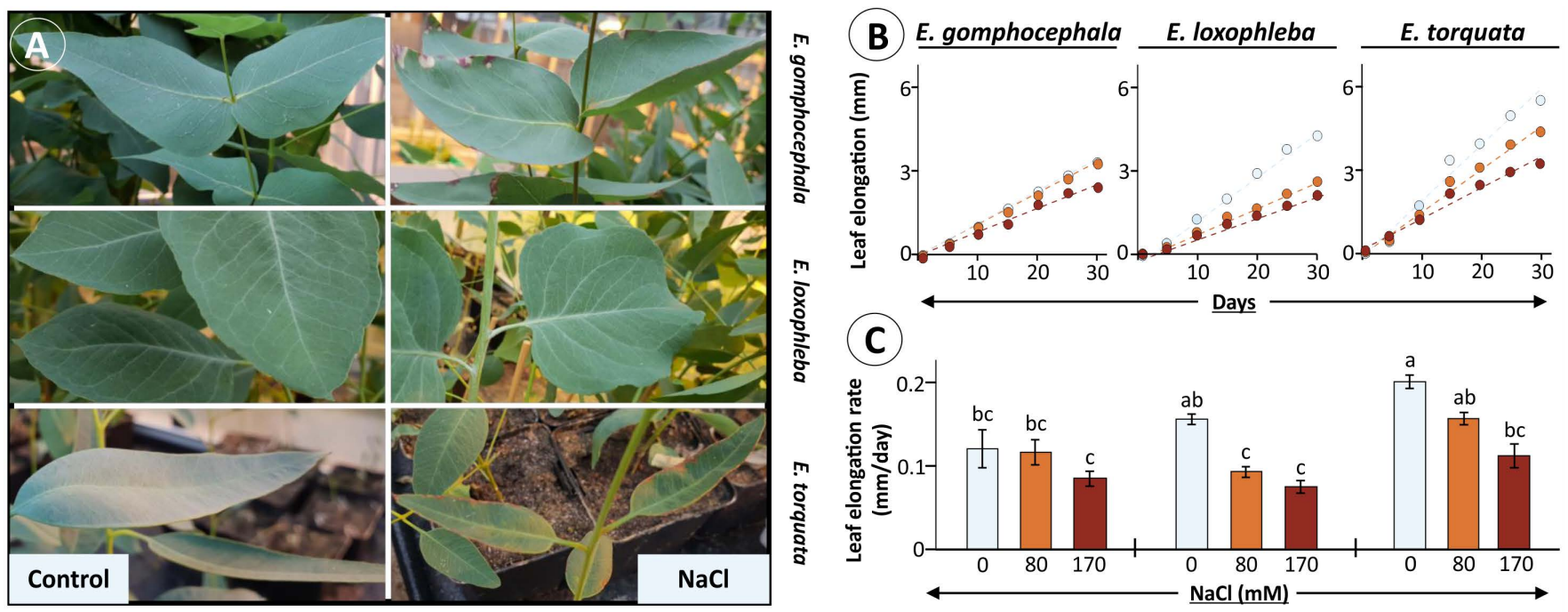

Figure 1. Leaf growth phenotype for Eucalyptus species under salt stress. Selected Eucalyptus species were exposed to increasing amounts of $\mathrm{NaCl}(0,80$ and $170 \mathrm{mM})$ and observed for leaf growth rates during $30 \mathrm{~d}$ of treatment. (A) Leaf phenotype as photographed after $30 \mathrm{~d}$ of maximum salt exposure to $170 \mathrm{mM}$. Measured leaf elongation presented as a growth-time curve (B) during treatment period along with calculated leaf elongation rate per day (C) for each species. Data for elongation rate per day $(C)$ are means $\pm \operatorname{SE}(n=8, p<0.05$; ANOVA and Tukey's post-hoc test).

\section{$C \bigcirc \mathrm{NaCl}(80 \mathrm{mM}) \bigcirc \mathrm{NaCl}(170 \mathrm{mM})$}

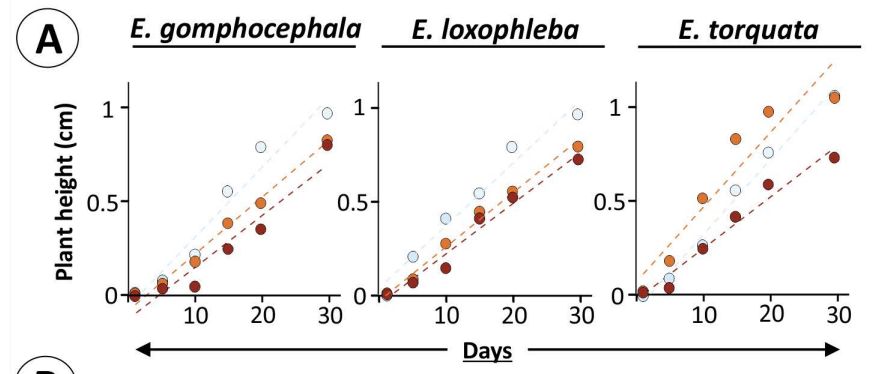

(B)
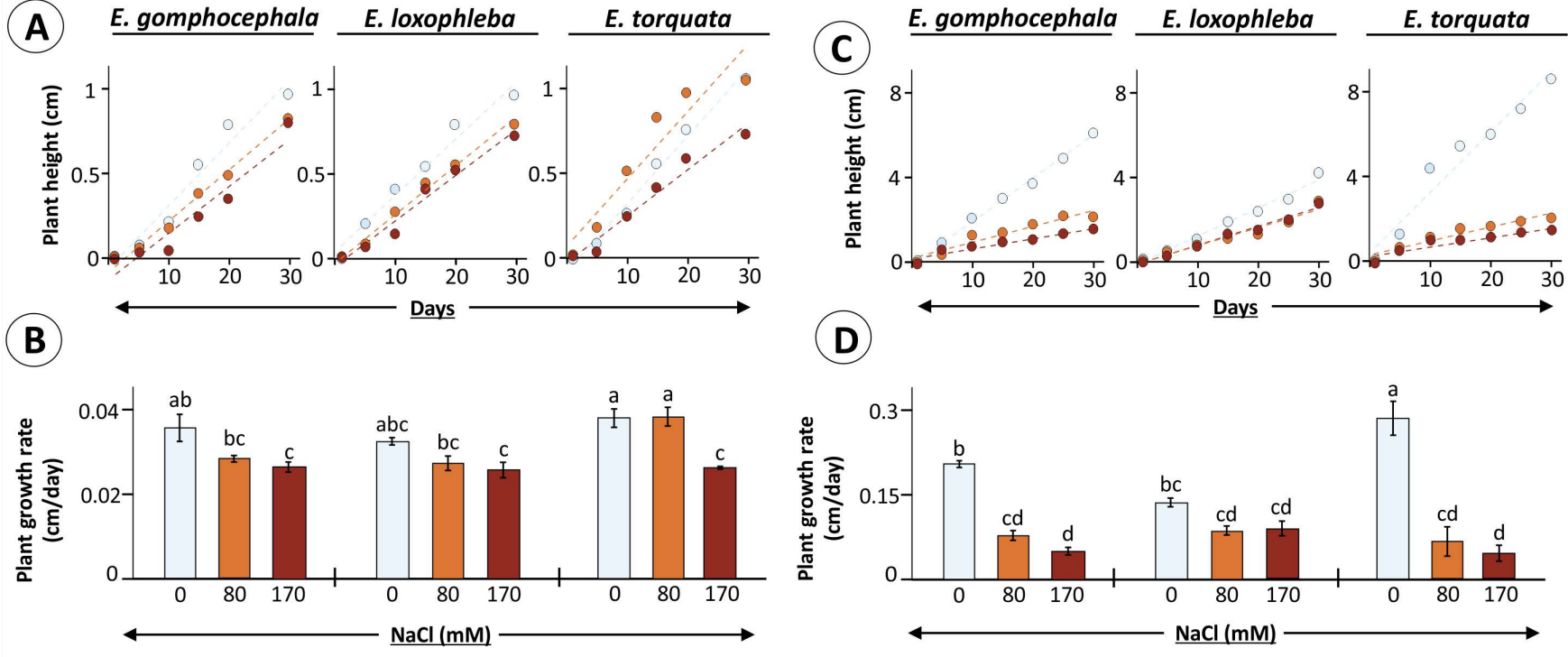

(D)

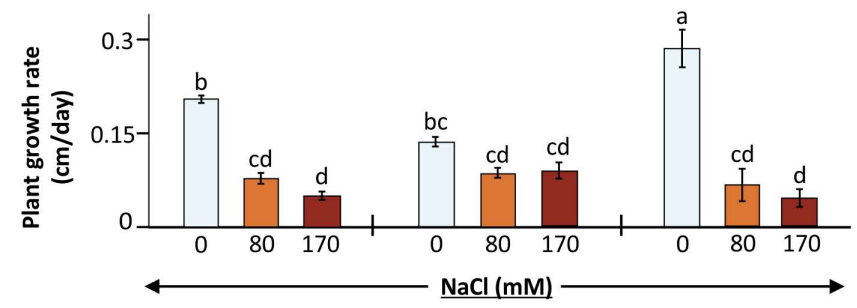

7 months old plants

13 months old plants

Figure 2. Eucalyptus plant growth as influenced by salt treatment. Eucalyptus species were exposed to $\mathrm{NaCl}$ ( 80 and $170 \mathrm{mM})$ added to the growth substrate after $6(\mathbf{A}, \mathbf{B})$ or $12(\mathbf{B}, \mathbf{C})$ months after germination and their growth was recorded during next $30 \mathrm{~d}$. In (B,D), data are means of plant growth rate \pm SE $(n=3-4, p<0.05$; ANOVA and Tukey's post-hoc test; bar diagrams). 
Data suggests that salt stress effects were plant age-dependent, where 7-month-old plants showed a $0-31 \%$ decrease in plant growth rate after $30 \mathrm{~d}$ salt exposure. Incidentally, the minimum (no change; $80 \mathrm{mM} \mathrm{NaCl}$ ) and maximum decrease $(31 \% ; 170 \mathrm{mM} \mathrm{NaCl}$ ) was observed for E. torquata (Figure 2B). The other two Eucalyptus species showed a steady decrease $(\sim 20 \%)$ already at $80 \mathrm{mM}$ treatment. Similarly, salt exposure for $30 \mathrm{~d}$ had more pronounced effects on 13-months-old plants, where treatment-specific decreases in plant growth rate were 62 and $76(\mathrm{Eg}), 36$ and $34(\mathrm{El})$, and 76 and $84 \%$ (Et) for 80 and $170 \mathrm{mM}$ $\mathrm{NaCl}$, respectively (Figure 2D). These observations point to growth responses as indicators of plant-specific stress tolerance mechanisms.

\subsection{Osmotic Balance and Ion Homeostasis in Plants under Salinity Stress}

In the present setup, ion accumulation $\left(\mathrm{K}^{+}, \mathrm{Na}^{+}\right.$, and $\left.\mathrm{Ca}^{2+}\right)$ was measured in young and old leaves of each Eucalyptus species and showed leaf age-dependent variations (Figure 3A-C; Supplementary Materials Figure S3). Salinity treatment led to increased $\mathrm{K}^{+}$ tissue contents in E. loxophleba young leaves (49 and 59\%) and old leaves (60 and 97\%) under 80 and $170 \mathrm{mM} \mathrm{NaCl}$, respectively. In comparison, no significant change was observed for $\mathrm{K}^{+}$ions in E. gomphocephala and E. torquata, except for a $93 \%$ rise for old Et leaves at $170 \mathrm{mM}$ (Figure $3 \mathrm{~A}$ ). Increased tissue $\mathrm{K}^{+}$serves to counterbalance accumulated $\mathrm{Na}^{+}$ and maintain a functional $\mathrm{K}^{+} / \mathrm{Na}^{+}$ratio. Measured $\mathrm{Na}^{+}$amounts revealed a prominent treatment-dependent accumulation in old leaves of all three Eucalyptus species, i.e., 1.64-, 2.47-fold (Eg), 2.12-, 2.64-fold (El), and 2.75-, 3.93-fold (Et) under 80 and $170 \mathrm{mM} \mathrm{NaCl}$, respectively (Figure $3 \mathrm{~B}$ ). In contrast, in young leaves in both $\mathrm{El}$ and $\mathrm{Eg}$, both treatments led to a similar increase of 2- and 4-fold, respectively, while the increase in $\mathrm{Na}^{+}$accumulation for Et was significantly different (4- and 6-fold) for increased NaCl-treatments (Figure 3A). Due to changes in $\mathrm{K}^{+}$and $\mathrm{Na}^{+}$accumulation with salinity, the $\mathrm{K}^{+} / \mathrm{Na}^{+}$ratio declined in both young (60\% for $\mathrm{Eg}$, El and 80\% for Et) and old leaves (40-60\% in Eg, 50\% in Et but only $25 \%$ in El) (Figure $3 \mathrm{C}$ ).

The relative water content (RWC) is an indicator of the water deficit encountered by the plants under salinity. Leaf RWC ranged between 90-70\%, where plants subjected to salt stress (80 and $170 \mathrm{mM} \mathrm{NaCl}$ ) showed significantly reduced RWC (Figure 3D). The degree of RWC decrease was higher for E. torquata as was also evident from a maximum 16\% drop in RWC for Et as compared to $9 \%$ in both $\mathrm{El}$ and $\mathrm{Eg}$, respectively, for $170 \mathrm{mM} \mathrm{NaCl}$ treatment (Figure 3D). EL, on the other hand, is a marker of plant plasma membrane integrity which is perturbed by ionic accumulation in plasmatic compartments and subsequent ROS accumulation. E. gomphocephala and E. loxophleba plants showed a 3- to 6-fold higher EL for the salt-treated leaves, but in comparison the leaves of E. torquata had 7- and 11-fold higher EL under 80 and $170 \mathrm{mM} \mathrm{NaCl}$, respectively (Figure 3E). 


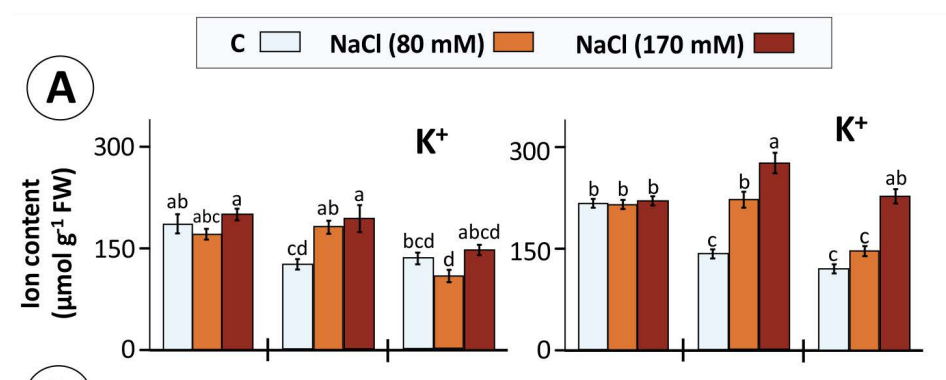

(B)

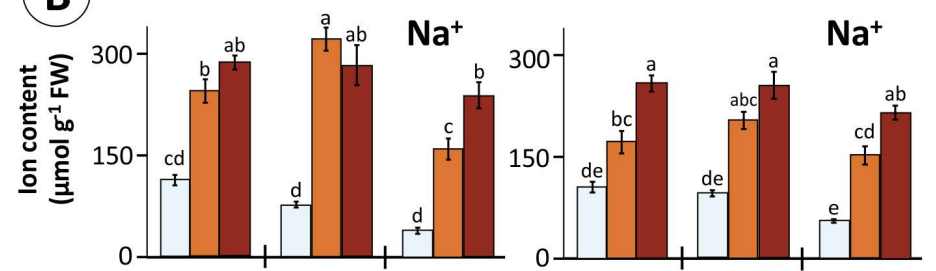

(C)

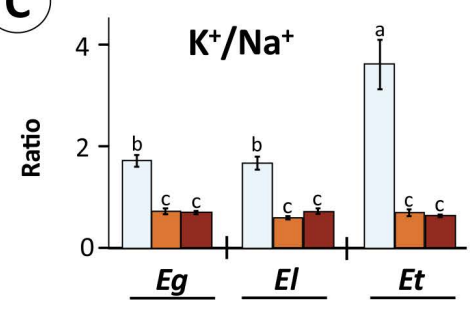

Young leaves

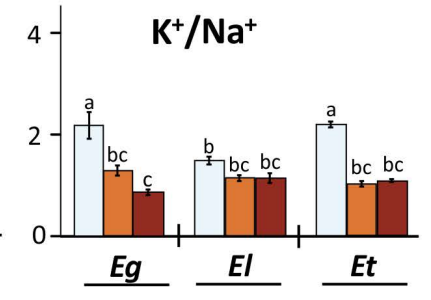

Old leaves

\section{E. gomphocephala $\bullet$ E. loxophleba $\bullet$ E. torquata}

(D)

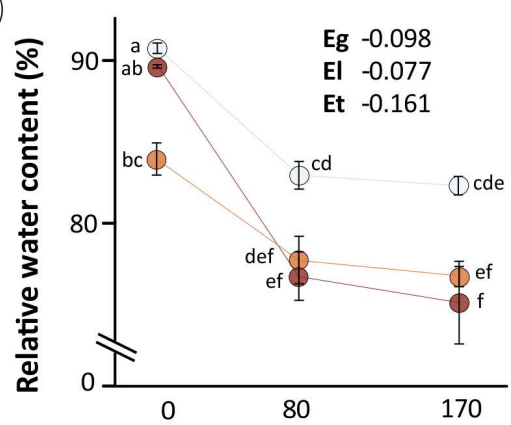

(E)

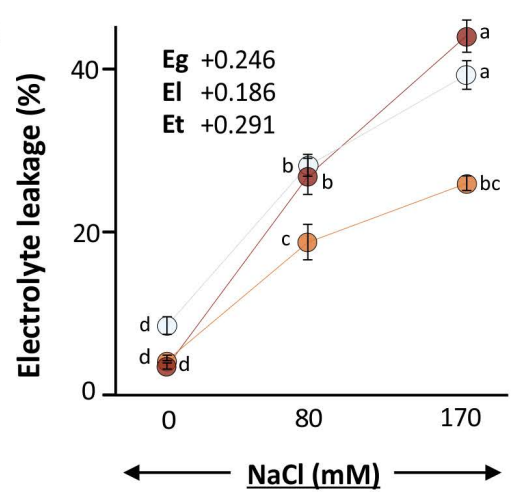

Figure 3. Osmotic and ionic burden as faced by Eucalyptus grown in saline conditions. Eucalyptus spp exposed to salinity (80 and $170 \mathrm{mM} \mathrm{NaCl}$ ) experienced both osmotic stress as well as ionic imbalance which was measured as tissue $\mathrm{K}^{+}$ (A) and $\mathrm{Na}^{+}$(B) contents in young and old Eucalyptus leaves and their ratios (C) as well as relative water content (RWC) (D) and membrane integrity (electrolyte leakage; EL) (E). RWC and EL scatter plots also provide values for slopes for each species indicating $\mathrm{NaCl}$ effects (only $80 \mathrm{mM}$ as effect saturates for $170 \mathrm{mM}$ ). Data are mean $\pm \mathrm{SE}, n=4$ (RWC, EL) and 5 (ion contents). $\mathrm{Ca}^{2+}$ contents are given in Supplementary Materials Figure S3A,B. Significant differences are based on ANOVA with Tukey's post-hoc test $(p<0.05)$.

\subsection{Photosynthesis and pETC: Working of PSII and PSI under Salinity Stress}

As noted above, salinity exposure in the present setup reduced chlorophyll as well as carotenoid contents with maximum change observed for E. torquata under both treatments. A similar pattern was observed for chlorophyll fluorescence-based parameters, especially in young leaves (Figure 4A-D). Overall, all parameters calculated showed the lowest values for E. torquata, where the operating PSII efficiency in light $\left(\mathrm{Fq}^{\prime} / \mathrm{Fm}^{\prime}\right)$ (Figure $4 \mathrm{~B}$ ) and ETR (Figure 4C) decreased further with salt treatments, as was also the case for qL (Figure 4D); however, this showed larger variability. The $\mathrm{Fq}^{\prime} / \mathrm{Fm}^{\prime}$ and ETR values showed similar patterns, as ETR is calculated based on $\mathrm{Fq}^{\prime} / \mathrm{Fm}^{\prime}$. In contrast to $\mathrm{Et}$, $\mathrm{Fq}^{\prime} / \mathrm{Fm}^{\prime}, \mathrm{Fq}^{\prime} / \mathrm{Fm}^{\prime}$ and ETR all had an increasing trend with salt treatment for E. loxophleba (Figure 4A-D).

In old leaves, however, the values for all parameters were highest for $\mathrm{El}$, without any apparent effect of salt treatment in El and Eg (Figure 4E-H). In Et old leaves, $80 \mathrm{mM}$ $\mathrm{NaCl}$ reduced the values for all parameters consistently, however they increased again for $170 \mathrm{mM}$ treatment. It needs emphasis that old leaves were those that started to grow before start of the treatment period, while young leaves originated by growth during one month of salt exposure. Further, one reason for observed uniformly low values for operating PSII efficiency in light might be the 90 min dark adaptation in between the light period (Figure 4). 
\begin{tabular}{|c|} 
C $\square \quad \mathrm{NaCl}(80 \mathrm{mM}) \square \quad \mathrm{NaCl}(170 \mathrm{mM}) \square$ \\
\hline $\mathrm{C} \mathrm{NaCl}(80 \mathrm{mM}) \bigcirc \mathrm{NaCl}(170 \mathrm{mM})$ \\
\hline
\end{tabular}
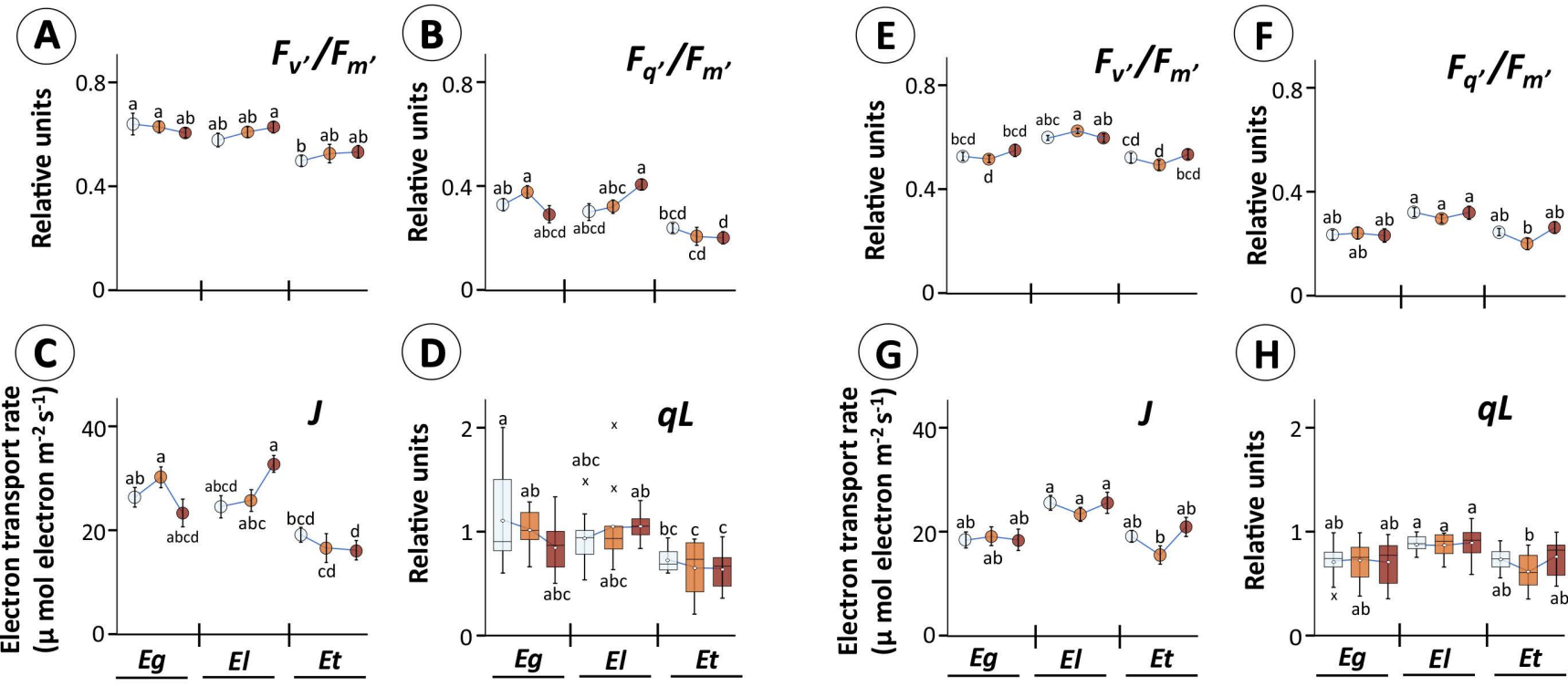

\section{(H)}
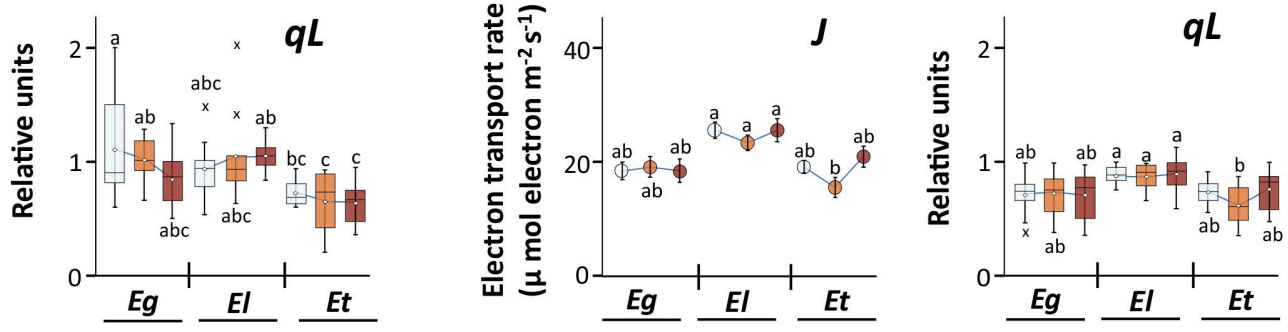

\section{Young leaves}

\section{Old leaves}

Figure 4. Efficiency of photosystem II (PSII) in selected Eucalyptus species exposed to salinity. Dark-adapted, detached young (A-D) and old leaves (E-H) of $30 \mathrm{~d}$ salt treated Eucalyptus species were exposed to actinic light $\left(160 \mu \mathrm{mol} \mathrm{m}^{-2} \mathrm{~s}^{-1}\right)$ for $17 \mathrm{~s}$ and chlorophyll a fluorescence recorded using the LED array spectrophotometer (DUAL-KLAS-NIR, Walz, Germany). Different parameters like maximum PSII efficiency in light $\left(F_{v^{\prime}} / F_{m^{\prime}}\right)(\mathbf{A}, \mathbf{E})$, operating PSII efficiency in light $\left(F_{q^{\prime}} / F_{m^{\prime}}\right)(\mathbf{B}, \mathbf{F})$, electron transport rate $(\mathrm{ETR} ; J)(\mathbf{C}, \mathbf{G})$, and estimated fraction of open PSII reaction centers ( $q L$; data given in form of box plots; $(\mathbf{D}, \mathbf{H})$ ) were calculated from chlorophyll a fluorescence data (means $\pm \mathrm{SE}, n=9-12, p<0.05$; ANOVA and Tukey's post-hoc test). (In box plots: hollow circle $=$ mean, the horizontal line in the box $=$ median, box limits $=25 \mathrm{th}$, 75th percentiles, whiskers extend 1.5 times the interquartile range from the 25 th and 75 th percentiles, not connected data points; cross $=$ outliers).

The efficiency of PSI and hence downstream carbon assimilation steps are not only determined by the activity or state of PSII, but by the balance between the pool sizes and the rate of reduction/oxidation of the acceptor (PC) and donor side (Fd) components for the P700 reaction center. In young Eucalyptus leaves, no major change in the maximum redox shift and pool size for PC, PSI and Fd was observed, except for the $80 \mathrm{mM} \mathrm{NaCl}$ treatment where the $\mathrm{Fd}$ response in Et was decreased compared to its control as well as that observed for El under $170 \mathrm{mM}$ salt (Supplementary Materials Table S3). In old leaves, maximum redox changes for PC and its pool size ratios relative to PSI were strongly lowered in E. torquata, especially under $170 \mathrm{mM}$ salt treatment (Supplementary Materials Table S3). Under the same treatment, the maximal redox change for PSI was highest for E. torquata. Further, light-dependent multiphasic redox changes recorded for PC, PSI and Fd for both young and old leaves are given in Figures 5 and 6. The evaluation considered multiple phases based on light-dependent electron flow upon dark-to-light transition, the rapidity of activation of reactions downstream to $\mathrm{Fd}$, the redox state in the steady state of light-driven reactions as well as the rapidity of redox change for the final light-dark. 
Major differences in redox state or respective rate of change were observed for old leaves, where more than one analyzed component, i.e., PC, PSI or Fd, showed a salt- or species-dependent variation. Also, among all compared phases of the redox kinetics in both young and old leaves, dark-to-light transitions or vice versa and the apparent steady state phase showed major differences (Figures 5 and 6). Further, both in young and old leaves, the acceptor side of PSI revealed more pronounced differences than the donor side (Figures 5 and 6). For example, in young leaves, the rate of PC reoxidation after $2 \mathrm{~s}$ of light exposure was strongly impeded by both salt treatments in Eg and Et, but not in El (Figure 5, phase 3). Similarly, rapid PC reduction upon darkening was lowered by salt exposure in $\mathrm{Eg}$ and $\mathrm{Et}$, but especially in $\mathrm{Et}$ by $170 \mathrm{mM} \mathrm{NaCl}$ (Figure 5, phase 5b). PC and PSI reoxidation rate and maximal values after reaching apparent steady state at $17 \mathrm{~s}$ of light exposure were also decreased in Et, however effects were not salt concentration-dependent (Figure 5, phase 4 and 5a).
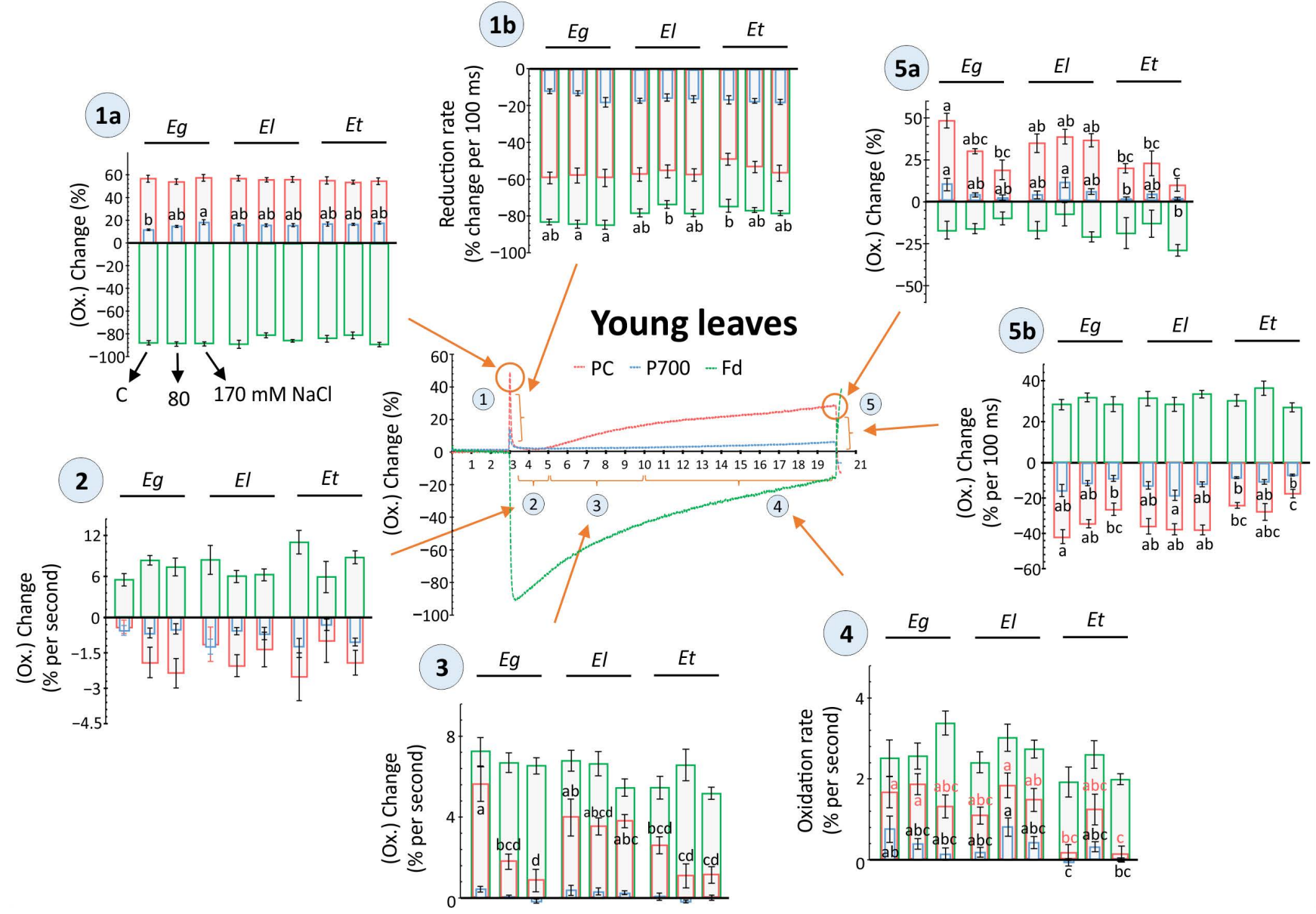

Figure 5. Light-driven redox changes for PC, P700 and Fd as recorded in young leaves of Eucalyptus spp under salt stress. Dark-adapted, detached young leaves of $30 \mathrm{~d}$ salt treated Eucalyptus spp were exposed to $160 \mu \mathrm{mol} \mathrm{m}^{-2} \mathrm{~s}^{-1}$ for $17 \mathrm{~s}$ and redox states of plastocyanins (PC), photosystem I (PSI) and ferredoxin (Fd) were recorded along with chlorophyll a fluorescence (Figure 4) using the DUAL-KLAS-NIR (Walz, Germany). The scatter plots depict representative kinetics of light-driven redox change at five different phases, as indicated i.e., 1(a, b), 2, 3, 4, 5 (a, b), based on light-dependent temporal shifts in the redox state of PC, PSI, and Fd (Phase $1=$ Dark to light shift, Phase 2, $3=$ dynamics of reoxidation, Phase $4=$ apparent steady state, Phase $5=$ end of light phase and light to dark shift. In phase 1 and 5 , ' $a$ ' = max. value, ${ }^{\prime} b^{\prime}$ = rate of redox shift). For individual phases, the redox changes were compared among plant species and different salt treatments and shown as histograms in form of the maximal changes or rates of redox transition (means $\pm \mathrm{SE}, n=9-12$, $p<0.05$; ANOVA and Tukey's post-hoc test). 


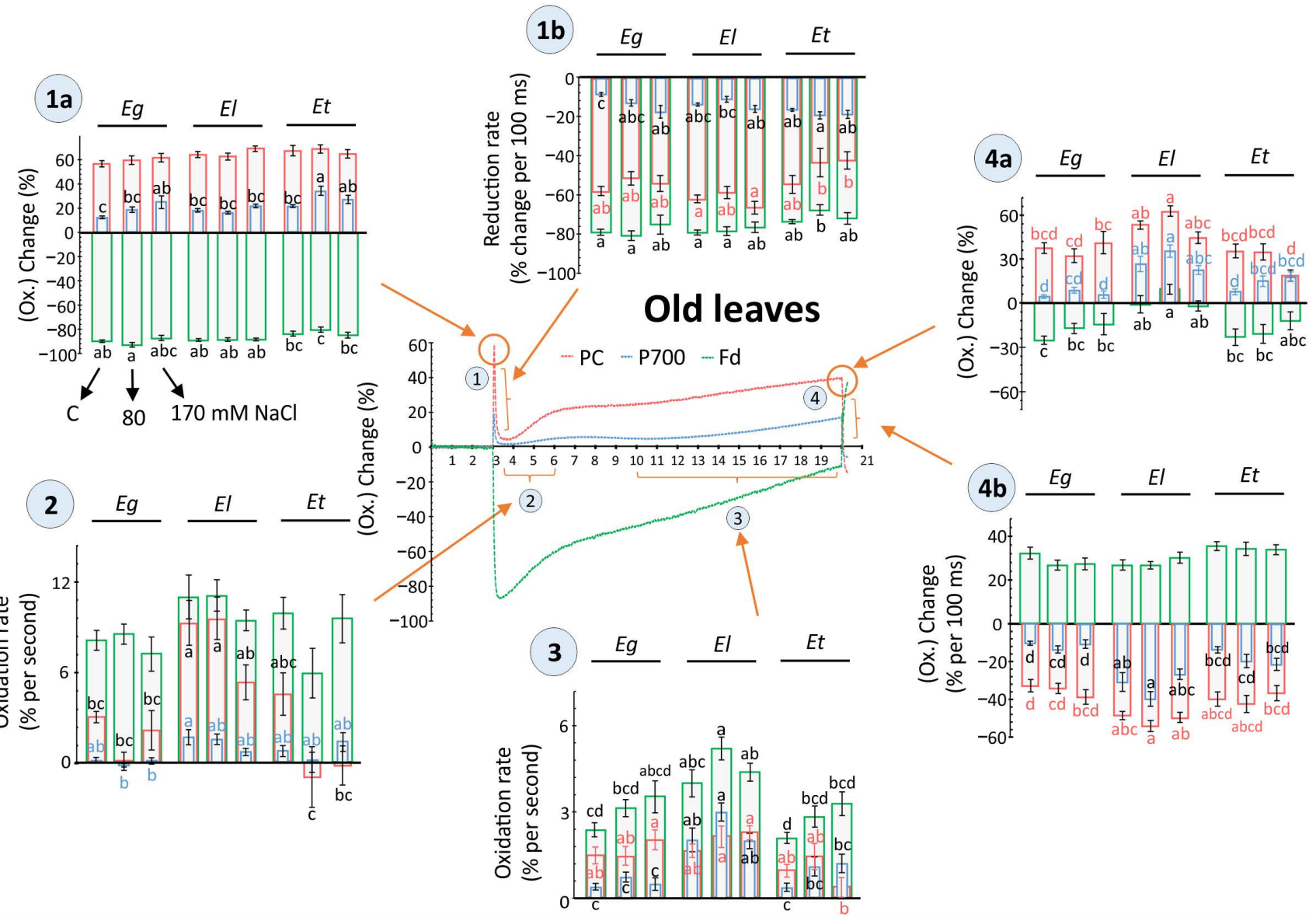

Figure 6. Light-driven redox changes for PC, P700 (PSI) and Fd as recorded in old leaves of Eucalyptus spp under salt stress. Dark-adapted, detached old leaves of $30 \mathrm{~d}$ salt treated Eucalyptus spp were exposed to $160 \mu \mathrm{mol} \mathrm{m}^{-2} \mathrm{~s}^{-1}$ for $17 \mathrm{~s}$ and redox states of plastocyanins (PC), photosystem I (PSI) and ferredoxin (Fd) were recorded along with chlorophyll a fluorescence (Figure 4) using the DUAL-KLAS-NIR (Walz, Germany). The scatter plot showing representative kinetics of light-driven redox change was divided into four different phases, as indicated i.e., 1(a, b), 2, 3, and 4(a, b), based on light-dependent temporal shifts in the redox state of PC, PSI, and Fd (Phase $1=$ Dark to light shift, Phase 2, 3= dynamics of reoxidation and apparent steady state, Phase $4=$ end of light phase and light to dark shift. In phase 1 and 4 , 'a' $=$ max. value, ' $b$ ' = rate of redox shift). For individual phases, the redox changes were compared among plant species and different salt treatments and are shown as histograms in form of maximal change or rate of redox transition (means $\pm \mathrm{SE}, n=9-12, p<0.05$; ANOVA and Tukey's post-hoc test). The data between 6-10 s were excluded due to observed high variance.

In old leaves, at the onset of light, maximum Fd reduction was decreased, while PSI oxidation was increased in Et plants treated with $80 \mathrm{mM}$ salt compared to others (Figure 6, phase 1a). Following the initial oxidation peak, PC reduction was strongly impeded by both salt treatments (Figure 6, phase 1b). Again, in the next reoxidation step, the rate for PC was lowered in $\mathrm{Et}$, compared to El, especially at $80 \mathrm{mM} \mathrm{NaCl}$ (Figure 6, phase 2). In the next slower reoxidation phase, the rate for PC was also lower under maximum salt treatment in Et (Figure 6, part 3). In the same phase, Fd oxidation rates were higher for $\mathrm{El}$, compared to control values in Eg and Et, while in all Eucalyptus spp salt had stimulating effects on $\mathrm{Fd}$ oxidation (Figure 6, phase 3). Maximum values at the apparent end of light phase were higher for all the components (PC, PSI, Fd) for El compared to Eg and Et, while $170 \mathrm{mM}$ $\mathrm{NaCl}$ decreased the maximal values for PC and Fd in Et (Figure 6, phase 4a). Similarly, higher rates of reduction were observed for El upon darkening, with no major effects of salt treatment (Figure 6, phase 4b). 


\subsection{Activities of Hydrolases}

The phosphatase activity in young leaves was significantly higher for $\mathrm{Eg}(76 \%)$ only at $170 \mathrm{mM}$ treatment, while it was 2.33, 2.47-fold and 1.89, 2.07-fold for El and Et, respectively, with increasing salt treatment (Figure 7A). In the old leaves, however, all three species showed a different behaviour, where for Eg the increase was significant only for $170 \mathrm{mM}$ $(61 \%)$, for Et the change was similarly higher for both treatments ( 1.65-fold), and old El leaves displayed a treatment specificity with 1.64- and 2.24-fold increase at 80 and $170 \mathrm{mM}$ $\mathrm{NaCl}$, respectively (Figure 7D). In the case of phosphodiesterase, in young leaves of all species, the increase in activity was treatment-dependent. Thus, a $17,82 \%(\mathrm{Eg}), 45,81 \%$ (El) and 33, 62\% (Et) increase was observed at 80 and $170 \mathrm{mM}$, respectively (Figure 7B). Conversely, the pattern of increase differed among the Eucalyptus species in old leaves (Figure 7E). Here, Eg showed treatment specificity with an increase of 48 and $64 \%$, while for El the increase was only significant at $170 \mathrm{mM}(70 \%)$. In E. torquata, the increase was similar for both treatments ( 34\%) (Figure 7E). $\beta$-galactosidase activity also increased differently among Eucalyptus species and leaf age types. For example, in young leaves of Eg (2.14-fold) and $\mathrm{Et}$ (1.93-fold) the only increase was for $170 \mathrm{mM} \mathrm{NaCl}$ treatment, while in the same case for El, both treatments led to a similar increase ( 2.65-fold) (Figure 7C). On the other hand, in old leaves, the increase was $25 \%(\mathrm{Eg} ; 170 \mathrm{mM}), \sim 80 \%$ (Et; both treatments) and a treatment-specific 61 and $84 \%$ (El; 80 and $170 \mathrm{mM}$, respectively) (Figure 7D).

In addition, notably higher constitutive catalase activity was observed in $\mathrm{El}$ and $\mathrm{Eg}$ compared to Et both in young and old leaves (Supplementary Materials Figure S4A,B). Catalase activity was significantly reduced in young (by $81,86 \%$ for 80 and $170 \mathrm{mM}$ $\mathrm{NaCl}$, respectively) and old leaves (by $71,79 \%$ for 80 and $170 \mathrm{mM} \mathrm{NaCl}$, respectively) of E. loxophleba, whereas the only significant decrease (75\%) for E. gomphocephala occurred in old leaves at $170 \mathrm{mM} \mathrm{NaCl}$ (Supplementary Materials Figure S4A,B). However, no significant change for catalase activity was observed for E. torquata on salt exposure.

\section{$C \square \mathrm{NaCl}(80 \mathrm{mM}) \square \quad \mathrm{NaCl}(170 \mathrm{mM})$}
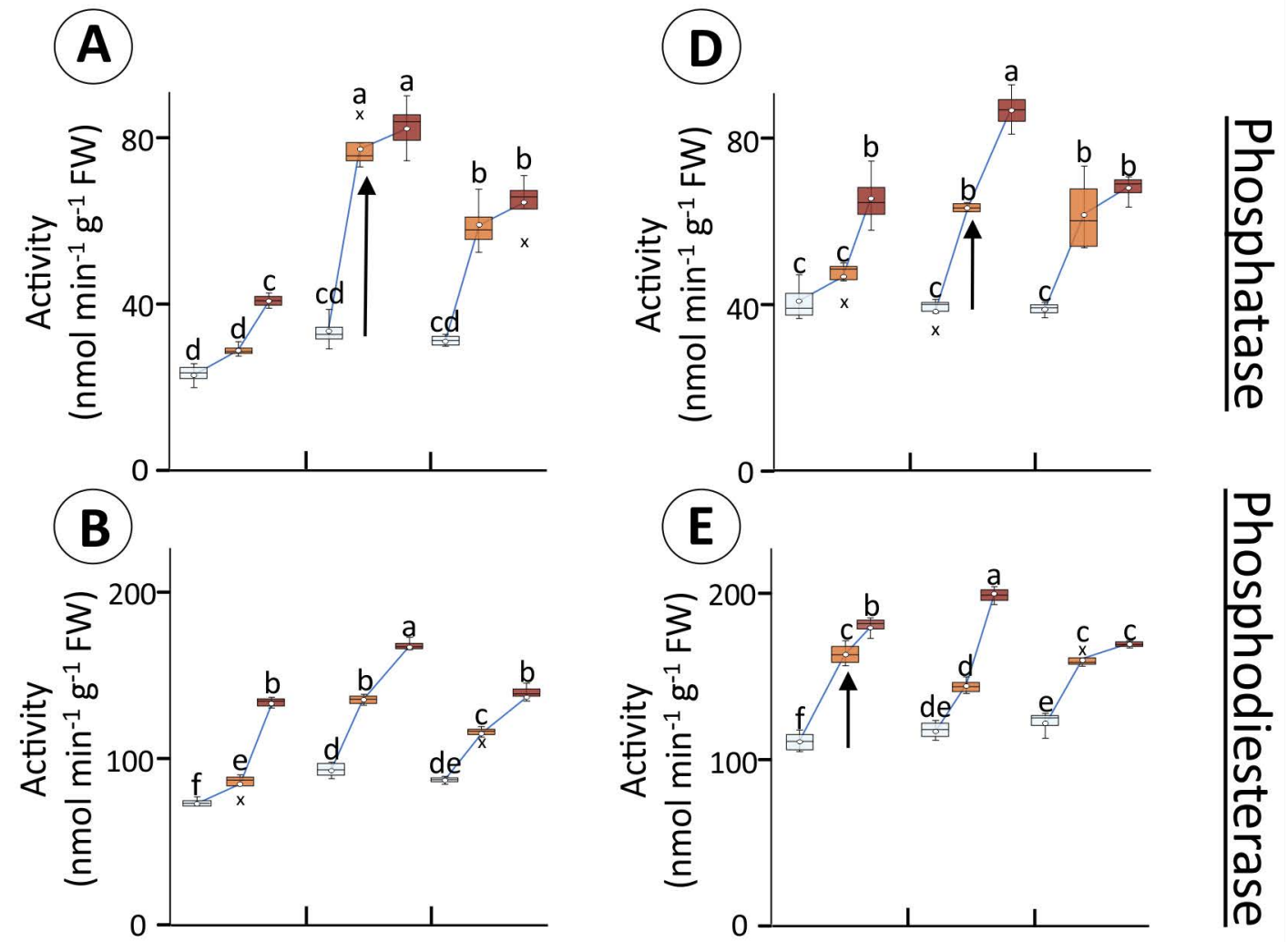

Figure 7. Cont. 

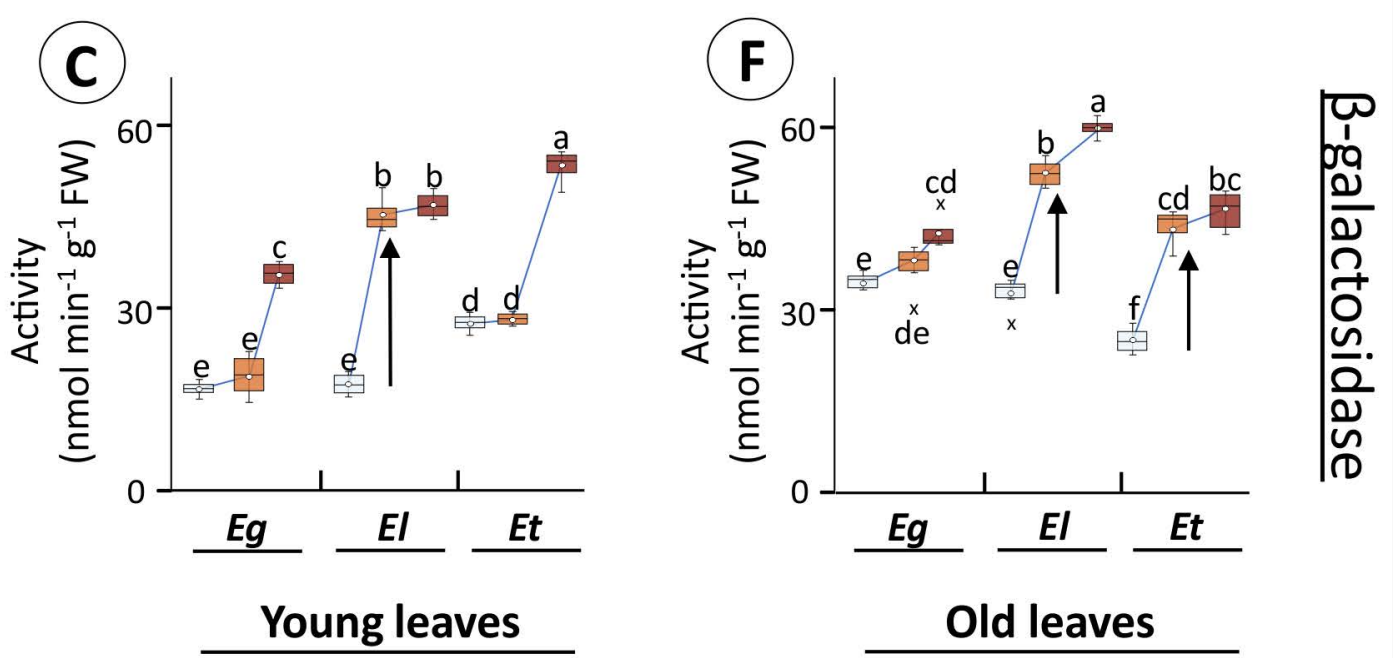

Figure 7. Activities of hydrolases in Eucalyptus leaf extracts in dependence on salt exposure. Activities of phosphatase (A,D), phosphodiesterase (B,E), and $\beta$-galactosidase (C,F) were measured in young and old leaves of $30 \mathrm{~d}$ salt ( 80 or 170 $\mathrm{mM} \mathrm{NaCl}$ )-treated Eucalyptus spp. Different letters indicate significance of difference after statistical analysis of the means ( $n=4, p<0.05$; ANOVA and Tukey's post-hoc test). (In box plots: hollow circle $=$ mean, the horizontal line in the box $=$ median, box limits $=25$ th, 75 th percentiles, whiskers extend 1.5 times the interquartile range from the 25th and 75th percentiles, not connected data points; cross = outliers).

\section{Discussion}

In plants, efficient salinity tolerance strategies involve complementary mechanisms at organ, cellular and subcellular levels. Examples for such crucial mechanisms are maintenance of osmotic balance through accumulation of osmolytes, compatible ion accumulation, protection of enzyme and membrane function in compartments, adjustment of redox balance, and the protection of photosynthetic machinery against oxidative damage as well as regulation of growth rates [2,17]. In the present setup, three Eucalyptus species which apparently possess differential salinity tolerance were compared. Eucalyptus plants are native to coastal regions and hence many species possess a natural ability to tolerate salinity [14]. The salt tolerance and sensitivity for E. loxophleba and E. torquata growing in different regions, respectively, are well documented features [15,43], while E. gomphocephala is a known coastal species and possesses drought tolerance traits [44].

Salt exposure studies in Eucalyptus have shown significant modulation of plant height and biomass accumulation in E. camaldulensis, E. sargentii, and E. loxophleba among other woody species $[15,45]$. Recorded phenotype, like appearance of necrotic spots and leaf browning and curling in E. gomphocephala and E. torquata indicated severe salt-induced damage at cellular level, especially in the latter (Figure 1A). Interestingly, continued high growth rates during $30 \mathrm{~d}$ salt treatment for 6-months old $E$. torquata plants could hint at inability to adjust balance between energy expenditure for growth and defence, which was efficiently portrayed by E. loxophleba plants (Figures $1 \mathrm{~B}$ and $2 \mathrm{~A}$ ). This hypothesis is supported by the constant 20-30\% decrease in growth for 7- or 13-month-old El plants under salinity, while the same was either 30 or $>80 \%$ for Et, respectively (Figure 2). Successful salt tolerance includes three mechanisms: (1) prevention of damage, (2) establishment of homeostasis and (3) adjustment of sustainable growth [46]. Such phenotypic plasticity is provided by various hormonal signaling pathways, along with the salt overly sensitive (SOS) signaling pathway [47-49]. This could indicate a regulated allocation of resources in El for management of the ionic/osmotic challenge, maintaining photosynthetic efficiency and prolonged survival under prevailing saline conditions for salt-tolerant plants as discussed below. 


\subsection{The Osmotic and Ionic Challenge}

Salinity inhibits plant growth via ionic imbalance and subsequent disruption of cellular metabolism [50]. The SOS signaling pathway has an established role in ion-homeostasis and regulates cellular $\mathrm{Na}^{+}$contents through extrusion and compartmentalization [49]. Recently, the sucrose non-fermentation-related protein kinases (SnRKs) of subgroup SnRK3, which participate in SOS signaling pathways, were characterized also in Eucalyptus species (E. grandis) [51]. Presented data from Tunisian Eucalyptus ecotype of E. torquata clearly indicated lack of regulation in $\mathrm{Na}^{+}$uptake or extrusion from roots as cellular $\mathrm{Na}^{+}$load increased in young and old leaves alike with increasing salt exposure (Figure 3A-C). Similar findings were reported for E. globulus, a species with greater susceptibility to salinity, as plants were unable to exclude $\mathrm{Na}^{+}$[14]. In contrast, $\mathrm{Na}^{+}$amounts in young leaves of E. loxophleba reached maximum levels at lower salt exposure but stayed unperturbed at higher salt exposures (Figure 3B).

In addition to SOS1-like $\mathrm{Na}^{+} / \mathrm{H}^{+}$antiporters or other overlapping $\mathrm{K}^{+} / \mathrm{Na}^{+}$transporters, the HKT category of transporters also take part in $\mathrm{Na}^{+}$exclusion and in maintaining high $\mathrm{K}^{+} / \mathrm{Na}^{+}$ratio to protect leaves [52]. Our results indicate a weak ability to properly regulate the $\mathrm{K}^{+} / \mathrm{Na}^{+}$ratio in young as well as old leaves of E. torquata (Figure 3C). The $\mathrm{K}^{+} / \mathrm{Na}^{+}$ratio also decreased significantly in $\mathrm{El}$ and $\mathrm{Eg}$, however at a substantially lower magnitude compared to Et, again highlighting a controlled $\mathrm{Na}^{+}$accumulation in Et. Potential deregulation of the SOS regulatory pathway, as appears to be the case, could also add to development of a severe stress phenotype, as SOS signals also regulate cell expansion and cell wall architecture [53] (Figure 3C). Ionic imbalances $\left(\mathrm{K}^{+} / \mathrm{Na}^{+}\right.$ratio) influence protein stability and function, $\mathrm{pH}$ regulation, membrane integrity, turgor adjustments as well as guard cell function, where $\mathrm{K}^{+}$is required [54-57]. Experimental evidence in Eucalyptus suggests a positive role of conditional $\mathrm{K}^{+}$fertilization in acclimation to water deprivation [58,59]. Impaired $\mathrm{K}^{+}-\mathrm{Na}^{+}$homeostasis could affect membrane integrity as was evident for both Eg and Et plants, where electrolyte leakage was substantially higher than El plants (Figure 3E).

Similar findings were reported for the moderately tolerant E. citriodora [15], where leaf $\mathrm{K}^{+}$as well as $\mathrm{K}^{+} / \mathrm{Na}^{+}$ratio dropped on salt exposure [60]. In contrast, salt-tolerant species like E. spathulate and E. sargentii possess the ability to selectively increase $\mathrm{K}^{+}$amounts over $\mathrm{Na}^{+}$[14], as is the case for E. loxophleba in the present study (Figure 3C). The responses of Eg young and old leaves in comparison to El and Et shows a clear example of a moderate response between salt tolerance and sensitivity. Another facet of salt stress is the perturbation of water relations. Ionic imbalance between soil and root affects water uptake, stomatal function and in turn carbon assimilation [27]. Osmotic adjustments in salt-tolerant species could protect against inhibition of normal photosynthetic efficiency. The highlighted moderate response for E. gomphocephala was apparent from the increased electrolyte leakage in the sensitive Et (Figure 3D). However, the changes in RWC were similar to the tolerant species El, indicating that RWC is a poorly related parameter (Figure 3D). Further characterization of sub-cellular ion $\left(\mathrm{K}^{+}, \mathrm{Na}^{+}\right.$etc.) accumulation and its temporal changes in moderately salinity tolerant/sensitive species like E. gomphocephala in contrast to the known tolerant and sensitive species is needed. This could help in finding the accumulation thresholds instrumental in activating the defense signaling pathways under salt stress.

\subsection{Perturbation in $p E T C$ Function}

Salinity effects on photosynthesis are manifested by multiple biochemical and physiological parameters; in particular, decreasing stomatal conductance affects gas exchange, $\mathrm{K}^{+}$ depletion- and Na-accumulation-induced enzyme inhibition decreases the carboxylation efficiency and oxidative stress affects cell redox homeostasis, metabolism and signaling [4]. The chlorophyll fluorescence-derived data in young leaves of salt-tolerant El indicated marginal stimulation of PSII efficiency in contrast to majorly negative effects in Eg and $\mathrm{Et}$, whereas in old leaves, constitutive values for all calculated parameters were higher in El (than both Eg and Et) with no negative salt effects (Figure 4). This could have con- 
tributed to a reduced but sustained growth of these plants without severe stress effects on leaves. Similar findings were also reported in other Eucalyptus studies [61]. In this context, chlorophyll a fluorescence-derived-parameters serve as meaningful indicators for the contrasting stress response in different cultivars/spp of a plant $[29,30,62,63]$. However, standard measurements are often limited to quantum yield efficiency of PSII only. The recent development of LED array spectrophotometer for in vivo application (DUAL-KLASNIR) has improved on this limitation by enabling simultaneous measurements of redox changes in components downstream of PSII in intact leaves [36] and was employed here.

Redox state kinetics of PC, PSI and Fd basically highlight how the state of plant photosynthesis and the rapidity of activation and deactivation of photochemistry differs among leaves along with how abiotic stresses may influence the rates [35,37-39]. The observed strong variability among biological replicates for the measurements indicates plasticity of the system to accommodate rapid adjustments that could be needed in response to changing environmental conditions (Figures 5 and 6). However, species-specific differences in the response of PC, PSI and Fd were recorded matching the physiology and biochemical analysis of the stress response (Figures 5 and 6). For example, young leaves of moderately tolerant E. gomphocephala plants showed salt-induced changes along with Et especially for PC and PSI (Figure 5). The rate of redox shift and redox state maxima remained relatively constant in El plants. In E. torquata plants, the dynamic range of the redox shift was lower, while Eg appeared similar to El at the start of the light phase but ended similarly to Et (Figure 5).

Salt effects were more pronounced in young leaves than old for these measurements. However, more species-dependent differences were visible for old leaves irrespective of strength of salt exposure. E. loxophleba plants showed higher flexibility in response to salt in old leaves then E. torquata, for example, at $170 \mathrm{mM}$ salt exposure (Figure 6). The higher dynamic range of El plants in old leaves overlapped with constantly higher values for chlorophyll fluorescence-derived PSII efficiency parameters (Figures 4 and 6). It is emphasized that such redox state measurements for PC, PSI and Fd could be useful to detect early signs of salinity tolerance/sensitivity in different plant species. Further, these detailed and deep biochemical features could be applied for molecular breeding in Eucalyptus-like tree species for salinity tolerance traits.

\subsection{Endomembrane Dynamics in Plant Growth and Stress Acclimation}

Subcellular membrane trafficking supports cell wall remodeling, cell proliferation and ion homeostasis among other fundamental processes [64]. Cellular $\mathrm{pH}$ homeostasis, ionic fluxes across membranes and hence regulation of $\mathrm{H}^{+}$pumps and cation $/ \mathrm{H}^{+}$transporterlike proteins drive membrane trafficking [65]. In this context, salt induced perturbations in $\mathrm{K}^{+}$distribution, selective $\mathrm{K}^{+} / \mathrm{Na}^{+}$-accumulation, nutrient signaling, and $\mathrm{pH}$ homeostasis are significant $[57,65,66]$. Therefore, as has been recently iterated [17], analysis of proteins in vacuoles, which are decisive compartments for $\mathrm{Na}^{+}$accumulation and ion homeostasis, is crucial.

In this study, activities of selected acid hydrolases, functional in acidic compartments of the cell (vacuole, apoplast), generally increased in all Eucalyptus species under salinity (Figure 7). Specifically, activities of phosphatase, phosphodiesterase, and $\beta$-galactosidase increased in young and old leaves of E. loxophleba (Figure 7). Recorded activity was strongly induced at $80 \mathrm{mM} \mathrm{NaCl}$, but only marginally at $170 \mathrm{mM}$, indicating activation of protective mechanisms at lower salt concentrations [67] (Figure 7). This pattern was similar for $\mathrm{Na}^{+}$ accumulation (Figures 3 and 7). This pattern of increase was generally stronger and unique for El compared to Eg and Et, pointing to potential sturdy endomembrane dynamics and regulation of $\mathrm{K}^{+}$-distribution (Figures $3 \mathrm{~A}, \mathrm{C}$ and 7). Such stimulation of membrane trafficking could result in observed changes in vacuolar dimensions for different plant species under abiotic stresses, especially under Cd or salt exposure [68-70]. Well-regulated protein activities for selected hydrolases in salt-tolerant species stipulate potential sustenance of such diverse pathways as protein metabolism, membrane functions, transport, stress 
signaling and cell wall biosynthetic processes for stress acclimation [71,72]. Apparently, these acid hydrolases may serve as sensitive and simple indicators allowing for titrating the salinity response and its saturation, as far as the contribution of the endomembrane dynamics is concerned.

\section{Materials and Methods}

\subsection{Experimental Setup and Growth under Salinity}

Seeds of E. gomphocephala A. Cunn. ex DC., E. loxophleba Benth., and E. torquata Luehm. were planted and grown in plastic pots filled with soil in a green house at $25 \pm 2{ }^{\circ} \mathrm{C}$, 150-200 $\mu \mathrm{mol}$ photons $\mathrm{m}^{-2} \mathrm{~s}^{-1}$ light intensity with a long day regime $(14 / 10 \mathrm{~h}$ day/night) and $55 \pm 2 \%$ RH for six months (if not stated otherwise) before exposure to salt stress. They were fertilized using commercial liquid fertilizer WUXAL Super $(0.1 \%)$ using $80 \mathrm{~mL}$ per pot once in two weeks. The composition of $0.1 \%$ nutritive solution was $\mathrm{N}(7.08 \mathrm{mM})$, $\mathrm{P}_{2} \mathrm{O}_{5}(0.35 \mathrm{mM}), \mathrm{K}_{2} \mathrm{O}(0.79 \mathrm{mM}), \mathrm{B}(24 \mu \mathrm{M}), \mathrm{Cu}(0.8 \mu \mathrm{M}), \mathrm{Fe}(4.5 \mu \mathrm{M}), \mathrm{Mn}(2.7 \mu \mathrm{M})$, Mo $(0.13 \mu \mathrm{M})$, and $\mathrm{Zn}(0.76 \mu \mathrm{M})$.

Eucalyptus plants were grown for six months or one year before $30 \mathrm{~d}$ of salt exposure $(0,80$ and $170 \mathrm{mM} \mathrm{NaCl}, 30$ plants per species, per treatment). Two different growth stages (7 and 13 months) were chosen to analyze the influence of seedling age on salinity-induced growth inhibition. Data presented in figures is labelled suitably when presenting data from both growth stages; otherwise, all other analysis was carried out in 7-month-old plants. For salinity application, the salt amount was progressively raised every second day in two sequential steps i.e., from 80 to 120 to $170 \mathrm{mM}$. The electrical conductance was measured with the ECTestr low+ conductivity meter (Oakton, Eutech Instruments Europe B.V., Netherlands) every second day to control the salt concentration in the soil and to adjust its levels by appropriate irrigation or saline solution. After $30 \mathrm{~d}$ of salt stress, young and old leaves from different biological replicates were harvested with instant freezing in liquid nitrogen and then stored at $80^{\circ} \mathrm{C}$ for further analysis.

\subsection{Osmotic and Ionic Challenge Posed by Salinity: Measure of Membrane Integrity and Ion Accumulation}

Electrolyte leakage, a measure for plasma membrane integrity, was measured for Eucalyptus leaves. Fresh leaves were harvested, washed with deionized water, and made into circular disks of $5 \mathrm{~mm}$ diameter. The leaf disks were incubated in glass tubes containing $10 \mathrm{~mL}$ of deionized water in a water bath at $32{ }^{\circ} \mathrm{C}$ for $2 \mathrm{~h}$ and the electrical conductance of the incubation solution was measured (EC 1) with the ECTestr low+ conductivity meter (Oakton, Eutech Instruments Europe B.V., Netherlands). The tubes were then autoclaved for $20 \mathrm{~min}$ to induce maximal loss of ions from cells and electric conductivity measured again (EC 2). Electrolyte leakage (EL) was calculated using Equation (1) [73].

$$
\mathrm{EL}=\frac{\mathrm{EC} 1}{\mathrm{EC} 2} * 100
$$

Relative water content (RWC) was measured with five leaves per sample. After weighing to obtain the actual fresh weight (FM), the leaves were immersed in $100 \mathrm{~mL}$ of distilled water for $6 \mathrm{~h}$ to obtain the weight of fully turgid leaves (TM). Leaves were dried at $60{ }^{\circ} \mathrm{C}$ for $48 \mathrm{~h}$ to determine dry weight (DM). The relative water content (RWC) was calculated according to Equation (2) [74]:

$$
\mathrm{RWC}=\frac{\mathrm{FM}-\mathrm{DM}}{\mathrm{TM}-\mathrm{DM}} * 100
$$

For estimation of ion accumulation, pulverized leaf tissue was extracted in $1 \mathrm{~mL}$ of $\mathrm{HNO}_{3}(1 \mathrm{M})$ in the Precellys ${ }^{\circledR}$ homogenizer $(3$ cycles of $6800 \mathrm{rpm}, 20 \mathrm{~s}$ each with $30 \mathrm{~s}$ pause every time). The homogenate was centrifuged at $16,000 \times \mathrm{g}$ for $10 \mathrm{~min}\left(4^{\circ} \mathrm{C}\right)$ and supernatant was used for ion contents quantification. $\mathrm{Na}^{+}, \mathrm{K}^{+}$and $\mathrm{Ca}^{2+}$ were determined in leaf extracts using a flame photometer (Model 410; Sherwood Scientific Ltd., Cambridge, 
UK) [75]. Standard solutions of $\mathrm{Na}^{+}, \mathrm{K}^{+}$and $\mathrm{Ca}^{2+}(0-10 \mathrm{ppm})$ were used to calibrate the flame photometer.

\subsection{Analysing Salt Stress Effects on Efficiency of $p E T C$}

The LED array spectrophotometer (DUAL-KLAS-NIR, Walz, Germany) facilitates measurements of chlorophyll a fluorescence as well as light-driven redox changes in PC, PSI and Fd. The measurement protocol was used as described with slight modifications [38,39]. Young and old leaves of differentially treated plants were detached and incubated in the dark with their petioles placed in water for 90 min before being analysed on the spectrophotometer. For analysis, leaves were fixed between emitter and detector with adaxial leaf surface facing the incident actinic light (photon flux density of $160 \mu \mathrm{mol} \mathrm{m}^{-2} \mathrm{~s}^{-1}$ ) or a saturating pulse of light. One standard measurement was $20 \mathrm{~s}$ long with an initial $3 \mathrm{~s}$ of dark measurement, followed by $17 \mathrm{~s}$ of actinic light. Recording was continued for $300 \mathrm{~ms}$ after switching off the actinic light.

Recorded chlorophyll a fluorescence data were utilized for calculating the following parameters:

$$
\begin{aligned}
& \text { Maximum PSII ef ficiency in light }\left(F_{V^{\prime}} / F_{m^{\prime}}\right)=\frac{\left(F_{m^{\prime}}-F_{o^{\prime}}\right)}{F_{m^{\prime}}} \\
& \text { Operating PSII efficiency in light }\left(F_{q^{\prime}} / F_{m^{\prime}}\right)=\frac{\left(F_{m^{\prime}}-F_{t}\right)}{F_{m^{\prime}}} \\
& \text { Electron transport rate }(J)=\left(F_{q^{\prime}} / F_{m^{\prime}}\right) \times(160) \times(0.5) \\
& \text { Estimation of open PSII reaction centers }(q L)=\frac{\left(F_{q^{\prime}} / F_{v^{\prime}}\right)}{\left(F_{o^{\prime}} / F_{t}\right)}
\end{aligned}
$$

where, $F_{o^{\prime}}=$ minimum fluorescence in light, $F_{m^{\prime}}=$ maximum fluorescence in light, $F_{t}=$ steady state fluorescence; for $J$, PFD was replaced by incident light assuming similar absorption for all samples, while 0.5 was the factor assumed for equal distribution of light between PSII and PSI. In addition, chlorophyll and carotenoid contents were measured independently in one-year-old plants after a prolonged ( 2 months) treatment.

For deconvolution of PC, PSI and Fd signals, model spectra generated with the leaves of E. camaldulensis were used. It needs emphasis here that E. camaldulensis is a well-recognized salt-tolerant Eucalyptus species and has been used for deconvolution here in all the salt treated plants for uniformity of background correction. Further, along with chlorophyll a fluorescence and light-driven redox changes for PC, PSI and Fd, another automated script, i.e., $\mathrm{NIR}_{\max }$ allowed measurement of maximum redox change for PC, PSI and Fd and was used to scale the redox shift to obtain absolute values as well as pool size ratios for PC and Fd relative to PSI. NIR $\max _{\max }$ measurements required dark adaptation. The kinetics of light-driven redox change here was divided into five phases as described in the figure legend.

\subsection{Enzyme in Antioxidant Defense and Endomembrane Metabolism: Testing Salt Stress Effects}

Salt stress due to ionic accumulation may lead to generation of ROS or inhibit enzyme activities/protein function in the target organelle. In the present setup, activities of the $\mathrm{H}_{2} \mathrm{O}_{2}$ scavenging enzyme catalase and the endomembrane system-associated vacuolar hydrolases phosphatase, phosphodiesterase and $\beta$-galactosidase were measured in all Eucalyptus spp. For protein extraction, fresh leaves were pulverized in liquid $\mathrm{N}_{2}$ and homogenized ( $\pm 100 \mathrm{mg}$ ) in $500 \mu \mathrm{L}$ of K-Pi buffer ( $50 \mathrm{mM}$; pH 6.8) containing $1 \mathrm{mM}$ phenylmethylsulfonylfluoride (PMSF) as protease inhibitor, using Precellys ${ }^{\circledR}$ homogenizer ( 3 cycles of $6800 \mathrm{rpm}, 20 \mathrm{~s}$ each with $30 \mathrm{~s}$ pause every time). The homogenate was centrifuged at $\sim 16,000 \times \mathrm{g}$ for $15 \mathrm{~min}\left(4^{\circ} \mathrm{C}\right)$ and the cleared extract was used for the assay. Protein content was determined spectrophotometrically at $595 \mathrm{~nm}$ using the Bradford assay [76]. 
Catalase activity was determined polarographically with a Clark-type $\mathrm{O}_{2}$ electrode [77]. The assay mixture contained K-Pi buffer ( $50 \mathrm{mM}$; pH 6.8) and $10 \mu \mathrm{L}$ extract, where after obtaining the baseline, the assay was started by adding $\mathrm{H}_{2} \mathrm{O}_{2}(40 \mathrm{mM})$. Catalase-specific activity was presented as nmol $\mathrm{min}^{-1} \mu \mathrm{g}^{-1}$ protein. Activity of hydrolytic enzymes phosphatase, phosphodiesterase and $\beta$-galactosidase was measured by determining the liberation of p-nitrophenol (PNP) from PNP-phosphate, bis-PNP-phosphate and PNP- $\beta$ galactopyranoside, respectively [78]. A fixed volume of protein extract was added to the reaction mixture $(400 \mu \mathrm{L})$ of citric acid- $\mathrm{KOH}(100 \mathrm{mM}$; pH 4.6) and $2 \mathrm{mg}$ of respective PNP substrate. After incubation for $60 \mathrm{~min}$ at $37^{\circ} \mathrm{C}$, the assay was stopped by adding $140 \mu \mathrm{L}$ $\mathrm{Na}_{2} \mathrm{CO}_{3}(1 \mathrm{M})$, and the absorption was measured at $405 \mathrm{~nm}$. Turnover rate was calculated using the molar extinction coefficient of p-nitrophenol $\left(\varepsilon=18.5 \mathrm{mM}^{-1} \mathrm{~cm}^{-1}\right)$.

\subsection{Statistical Analysis}

Values presented are means \pm SE, if not mentioned otherwise. The data were analyzed for significance of difference using IBM SPSS Statistics 21 software. Data were subjected to analysis of variance (ANOVA) followed by post-hoc analysis (Tukey's test; $p<0.05$ level). Means not labelled with letters show no statistically significant differences. Plant height and leaf elongation were measured every 5th day. The values for leaf size and plant height were normalized in a way to highlight changes during the $30 \mathrm{~d}$ stress. For this, the values collected before treatment were subtracted from all values recorded during treatment duration and data presented in Figures 1 and 2. To emphasize the observed differences in growth, trend-lines are shown for normalized data in both figures.

\section{Conclusions}

The efficient ionic and osmotic balance maintenance in El plants highlights the salinity tolerance feature of this Eucalyptus species, in contrast to moderate or low salt tolerance as observed for Eg and Et species, respectively. The early response to salt exposure shown by hydrolytic enzymes, especially in the tolerant species El, further highlights the importance and need for detailed investigation into the dynamic nature of the vacuole and apoplast function under salinity. The results here show two crucial aspects of pETC functioning: (a) the variability of the constitutive response for these Eucalyptus species to dark-light transitions, and (b) the impact of the salt treatment. Since the first response was as equally prominent as the salinity effects, it was tedious to distinguish the two in certain cases. This further highlights that the observed differences have implications for not only salinity stress, but water deprivation in general, due to their direct influence on photosynthesis.

Supplementary Materials: The following are available online at https:/ / www.mdpi.com/article/ 10.3390/plants10071401/s1, Figure S1: Comparison of accumulated biomass (fresh and dry weight of leaves, stem, and roots) for optimally grown E. gomphocephala, E. loxophleba and E. torquata, Figure S2: Leaf pigment contents of E. gomphocephala, E. loxophleba and E. torquata as affected by salt treatment, Figure S3: $\mathrm{Ca}^{2+}$-contents of leaf tissue from salt exposed E. gomphocephala, E. loxophleba and E. torquata, Figure S4: Catalase activity of E. gomphocephala, E. loxophleba and E. torquata leaves under salinity stress, Table S1: Germination of multiple Eucalyptus spp from Tunisia exposed to increasing concentrations of salt $(0-210 \mathrm{mM} \mathrm{NaCl})$, Table S2: Root and shoot growth data from multiple Eucalyptus spp exposed to increasing concentrations of salt (0-210 mM NaCl), Table S3: Maximum redox change and ratio of pool sizes for PC, P700 and Fd in salt-treated Eucalyptus spp (E. gomphocephala, E. loxophleba and E. torquata) estimated after dark adaptation using DUAL-KLASNIR spectrophotometer.

Author Contributions: Conceptualization, M.A., H.B. and K.-J.D.; methodology, H.B., V.K. and K.-J.D.; formal analysis, investigation, data curation, visualization, and writing-original draft preparation, H.B. and V.K.; writing-review, editing, supervision, resources and funding acquisition, M.A. and K.-J.D. All authors have read and agreed to the published version of the manuscript.

Funding: This research received no external funding.

Institutional Review Board Statement: Not applicable. 
Informed Consent Statement: Not applicable.

Data Availability Statement: Data are contained within the article and supplementary materials.

Acknowledgments: Authors acknowledge the laboratory support and guidance provided by Lara Vogelsang and Martina Holt. VK acknowledges financial support from faculty of biology, University Bielefeld.

Conflicts of Interest: The authors declare to not encounter any conflict of interest. The funders had no role in the design of the study; in the collection, analyses, or interpretation of data; in the writing of the manuscript, or in the decision to publish the results.

\section{References}

1. Parihar, P.; Singh, S.; Singh, R.; Singh, V.P.; Prasad, S.M. Effect of salinity stress on plants and its tolerance strategies: A review. Environ. Sci. Pollut. Res. 2015, 22, 4056-4075. [CrossRef] [PubMed]

2. Acosta-Motos, J.R.; Ortuño, M.F.; Bernal-Vicente, A.; Diaz-Vivancos, P.; Sanchez-Blanco, M.J.; Hernandez, J.A. Plant Responses to Salt Stress: Adaptive Mechanisms. Agronomy 2017, 7, 18. [CrossRef]

3. Negrao, S.; Schmöckel, S.M.; Tester, M. Evaluating physiological responses of plants to salinity stress. Ann. Bot. 2017, 119, 1-11. [CrossRef]

4. Chaves, M.M.; Flexas, J.; Pinheiro, C. Photosynthesis under drought and salt stress: Regulation mechanisms from whole plant to cell. Ann. Bot. 2008, 103, 551-560. [CrossRef] [PubMed]

5. Nielsen, D.L.; Brock, M.A.; Rees, G.; Baldwin, D.S. Effects of increasing salinity on freshwater ecosystems in Australia. Aust. J. Bot. 2003, 51, 655-665. [CrossRef]

6. Wilson, B.J.; Servais, S.; Mazzei, V.; Kominoski, J.S.; Hu, M.; Davis, S.E.; Gaiser, E.; Sklar, F.; Bauman, L.; Kelly, S.; et al. Salinity pulses interact with seasonal dry-down to increase ecosystem carbon loss in marshes of the Florida Everglades. Ecol. Appl. 2018, 28, 2092-2108. [CrossRef]

7. Mota-Cadenas, C.; Alcaraz-López, C.; Martínez-Ballesta, M.C.; Carvajal, M. How Salinity Affects Co2 Fixation by Horticultural Crops. HortScience 2010, 45, 1798-1803. [CrossRef]

8. Berger, E.; Frör, O.; Schäfer, R.B. Salinity impacts on river ecosystem processes: A critical mini-review. Philos. Trans. R. Soc. B Biol. Sci. 2018, 374, 20180010. [CrossRef]

9. Minhas, P.; Yadav, R.; Bali, A. Perspectives on reviving waterlogged and saline soils through plantation forestry. Agric. Water Manag. 2020, 232, 106063. [CrossRef]

10. Ruprecht, J.; Sparks, T.; Liu, N.; Dell, B.; Harper, R. Using reforestation to reverse salinisation in a large watershed. J. Hydrol. 2019, 577, 123976. [CrossRef]

11. Hasanuzzaman, M.; Nahar, K.; Alam, M.; Bhowmik, P.C.; Hossain, A.; Rahman, M.M.; Prasad, M.N.V.; Ozturk, M.; Fujita, M. Potential Use of Halophytes to Remediate Saline Soils. BioMed Res. Int. 2014, 2014, 1-12. [CrossRef]

12. Leksungnoen, N.; Andriyas, T. Enhancing the salt tolerance of commercial Eucalyptus hybrid seedlings in preparation for reclamation of inland salinity areas. Eur. J. For. Res. 2019, 138, 803-812. [CrossRef]

13. Shi, Z.; Xu, D.; Yang, X.; Jia, Z.; Guo, H.; Zhang, N. Ecohydrological impacts of eucalypt plantations: A review. J. Food Agric. Environ. 2012, 10, 1419-1426.

14. Adams, M.; Richter, A.; Hill, A.K.; Colmer, T.D. Salt tolerance in Eucalyptus spp.: Identity and response of putative osmolytes. Plant Cell Environ. 2005, 28, 772-787. [CrossRef]

15. Niknam, S.; McComb, J. Salt tolerance screening of selected Australian woody species-A review. For. Ecol. Manag. 2000, 139, 1-19. [CrossRef]

16. Fox, J.; Neilsen, J.; Osborne, J. Eucalyptus seedling growth and salt tolerance from the north-eastern goldfields of Western Australia. J. Arid Environ. 1990, 19, 45-53. [CrossRef]

17. Isayenkov, S.V.; Maathuis, F.J.M. Plant Salinity Stress: Many Unanswered Questions Remain. Front. Plant Sci. 2019, 10, 80. [CrossRef] [PubMed]

18. Zörb, C.; Geilfus, C.M.; Dietz, K.J. Salinity and crop yield. Plant Biol. 2019, 21, 31-38. [CrossRef]

19. Pilar, C.; Antonio, O.; Antonio, C. Effects of saline stress and calcium on lipid composition in bean roots. Phytochemistry 1993, 32, 1131-1136. [CrossRef]

20. Kataria, S.; Verma, S.K. Salinity Stress Responses and Adaptive Mechanisms in Major Glycophytic Crops: The Story So Far. In Salinity Responses and Tolerance in Plants, Volume 1: Targeting Sensory, Transport and Signaling Mechanisms; Kumar, V., Wani, S.H., Suprasanna, P., Tran, L.-S.P., Eds.; Springer International Publishing: Cham, Switzerland, 2018; pp. 1-39. [CrossRef]

21. Mbarki, S.; Sytar, O.; Cerda, A.; Zivcak, M.; Rastogi, A.; He, X.; Zoghlami, A.; Abdelly, C.; Brestic, M. Strategies to Mitigate the Salt Stress Effects on Photosynthetic Apparatus and Productivity of Crop Plants. In Salinity Responses and Tolerance in Plants, Volume 1: Targeting Sensory, Transport and Signaling Mechanisms; Kumar, V., Wani, S.H., Suprasanna, P., Tran, L.-S.P., Eds.; Springer International Publishing: Cham, Switzerland, 2018; pp. 85-136. [CrossRef]

22. Deinlein, U.; Stephan, A.B.; Horie, T.; Luo, W.; Xu, G.; Schroeder, J.I. Plant salt-tolerance mechanisms. Trends Plant Sci. 2014, 19, 371-379. [CrossRef] 
23. Bor, M.; Özdemir, F. Manipulating Metabolic Pathways for Development of Salt-Tolerant Crops. In Salinity Responses and Tolerance in Plants, Volume 1: Targeting Sensory, Transport and Signaling Mechanisms; Kumar, V., Wani, S.H., Suprasanna, P., Tran, L.-S.P., Eds.; Springer International Publishing: Cham, Switzerland, 2018; pp. 235-256. [CrossRef]

24. Baetz, U.; Eisenach, C.; Tohge, T.; Martinoia, E.; De Angeli, A. Vacuolar Chloride Fluxes Impact Ion content and Distribution during Early Salinity Stress. Plant Physiol. 2016, 172, 1167-1181. [CrossRef]

25. Kumar, K.; Saddhe, A.A. Targeting Aquaporins for Conferring Salinity Tolerance in Crops. In Salinity Responses and Tolerance in Plants, Volume 1: Targeting Sensory, Transport and Signaling Mechanisms; Kumar, V., Wani, S.H., Suprasanna, P., Tran, L.-S.P., Eds.; Springer International Publishing: Cham, Switzerland, 2018; pp. 65-84. [CrossRef]

26. Duggleby, R.G.; Dennis, D.T. Pyruvate Kinase, a Possible Regulatory Enzyme in Higher Plants. Plant Physiol. 1973, 52, $312-317$. [CrossRef]

27. Shabala, S.; Cuin, T.A. Potassium transport and plant salt tolerance. Physiol. Plant. 2008, 133, 651-669. [CrossRef]

28. Rubio, F.; Nieves-Cordones, M.; Horie, T.; Shabala, S. Doing 'business as usual' comes with a cost: Evaluating energy cost of maintaining plant intracellular K+ homeostasis under saline conditions. New Phytol. 2020, 225, 1097-1104. [CrossRef]

29. Duarte, B.; Santos, D.; Marques, J.C.; Caçador, I. Ecophysiological adaptations of two halophytes to salt stress: Photosynthesis, PS II photochemistry and anti-oxidant feedback-Implications for resilience in climate change. Plant Physiol. Biochem. 2013, 67, 178-188. [CrossRef]

30. Stepien, P.; Johnson, G.N. Contrasting Responses of Photosynthesis to Salt Stress in the Glycophyte Arabidopsis and the Halophyte Thellungiella: Role of the Plastid Terminal Oxidase as an Alternative Electron Sink. Plant Physiol. 2009, 149, 1154-1165. [CrossRef] [PubMed]

31. Parida, A.K.; Das, A.B. Salt tolerance and salinity effects on plants: A review. Ecotoxicol. Environ. Saf. 2005, 60, 324-349. [CrossRef] [PubMed]

32. Lee, M.H.; Cho, E.J.; Wi, S.G.; Bae, H.; Kim, J.E.; Cho, J.-Y.; Lee, S.; Kim, J.-H.; Chung, B.Y. Divergences in morphological changes and antioxidant responses in salt-tolerant and salt-sensitive rice seedlings after salt stress. Plant Physiol. Biochem. 2013, 70, 325-335. [CrossRef] [PubMed]

33. Moradi, F.; Ismail, A.M. Responses of Photosynthesis, Chlorophyll Fluorescence and ROS-Scavenging Systems to Salt Stress During Seedling and Reproductive Stages in Rice. Ann. Bot. 2007, 99, 1161-1173. [CrossRef] [PubMed]

34. Hossain, S.; Edietz, K.-J. Tuning of Redox Regulatory Mechanisms, Reactive Oxygen Species and Redox Homeostasis under Salinity Stress. Front. Plant Sci. 2016, 7, 548. [CrossRef] [PubMed]

35. Klughammer, C.; Schreiber, U. Deconvolution of ferredoxin, plastocyanin, and P700 transmittance changes in intact leaves with a new type of kinetic LED array spectrophotometer. Photosynth. Res. 2016, 128, 195-214. [CrossRef] [PubMed]

36. Schreiber, U.; Klughammer, C. Analysis of photosystem I donor and acceptor sides with a new type of online-deconvoluting kinetic LED-array spectrophotometer. Plant Cell Physiol. 2016, 57, 1454-1467. [CrossRef] [PubMed]

37. Schreiber, U. Redox changes of ferredoxin, P700, and plastocyanin measured simultaneously in intact leaves. Photosynth. Res. 2017, 134, 343-360. [CrossRef] [PubMed]

38. Kumar, V.; Vogelsang, L.; Seidel, T.; Schmidt, R.; Weber, M.; Reichelt, M.; Meyer, A.; Clemens, S.; Sharma, S.S.; Dietz, K.-J. Interference between arsenic-induced toxicity and hypoxia. Plant Cell Environ. 2018, 42, 574-590. [CrossRef] [PubMed]

39. Vaseghi, M.-J.; Chibani, K.; Telman, W.; Liebthal, M.F.; Gerken, M.; Schnitzer, H.; Mueller, S.M.; Dietz, K.-J. The chloroplast 2-cysteine peroxiredoxin functions as thioredoxin oxidase in redox regulation of chloroplast metabolism. Elife 2018, 7, e38194. [CrossRef]

40. Lima-Melo, Y.; Gollan, P.J.; Tikkanen, M.; Silveira, J.A.G.; Aro, E.-M. Consequences of photosystem-I damage and repair on photosynthesis and carbon use in Arabidopsis thaliana. Plant J. 2018, 97, 1061-1072. [CrossRef] [PubMed]

41. Shimakawa, G.; Miyake, C. Changing frequency of fluctuating light reveals the molecular mechanism for P700 oxidation in plant leaves. Plant Direct 2018, 2, e00073. [CrossRef]

42. Telman, W.; Liebthal, M.; Dietz, K.-J. Redox regulation by peroxiredoxins is linked to their thioredoxin-dependent oxidase function. Photosynth. Res. 2019, 145, 31-41. [CrossRef]

43. Wahbi, J.; Kaouther, M. Micromorphological observation of seed of Eucalyptus species and multivariate statistical analyses and modeling of their germination under salt stress and osmotic constraint. CERNE 2019, 125, 156-171.

44. Wessels, C.B.; Crafford, P.L.; Dutoit, B.; Grahn, T.; Johansson, M.; Lundqvist, S.O.; Säll, H.; Seifert, T. Variation in physical and mechanical properties from three drought tolerant Eucalyptus species grown on the dry west coast of Southern Africa. Eur. J. Wood Wood Prod. 2016, 74, 563-575. [CrossRef]

45. Shariat, A.; Assareh, M.H. Physiological and Biochemical Responses of Eight Eucalyptus Species to Salinity Stress. Ecopersia 2016, 4, 1269-1282. [CrossRef]

46. Zhu, J.-K. Plant salt tolerance. Trends Plant Sci. 2001, 6, 66-71. [CrossRef]

47. Sreenivasulu, N.; Harshavardhan, V.T.; Govind, G.; Seiler, C.; Kohli, A. Contrapuntal role of ABA: Does it mediate stress tolerance or plant growth retardation under long-term drought stress? Gene 2012, 506, 265-273. [CrossRef] [PubMed]

48. Yu, Z.; Duan, X.; Luo, L.; Dai, S.; Ding, Z.; Xia, G. How Plant Hormones Mediate Salt Stress Responses. Trends Plant Sci. 2020, 25, 1117-1130. [CrossRef]

49. Ji, H.; Pardo, J.M.; Batelli, G.; Van Oosten, M.; Bressan, R.A.; Li, X. The Salt Overly Sensitive (SOS) Pathway: Established and Emerging Roles. Mol. Plant 2013, 6, 275-286. [CrossRef] 
50. Munns, R.; Tester, M. Mechanisms of salinity tolerance. Annu. Rev. Plant Biol. 2008, 59, 651-681. [CrossRef] [PubMed]

51. Wang, Y.; Yan, H.; Qiu, Z.; Hu, B.; Zeng, B.; Zhong, C.; Fan, C. Comprehensive Analysis of SnRK Gene Family and their Responses to Salt Stress in Eucalyptus grandis. Int. J. Mol. Sci. 2019, 20, 2786. [CrossRef]

52. Hauser, F.; Horie, T. A conserved primary salt tolerance mechanism mediated by HKT transporters: A mechanism for sodium exclusion and maintenance of high $\mathrm{K}+/ \mathrm{Na}+$ ratio in leaves during salinity stress. Plant, Cell Environ. 2010, 33, 552-565. [CrossRef]

53. Mahajan, S.; Pandey, G.K.; Tuteja, N. Calcium- and salt-stress signaling in plants: Shedding light on SOS pathway. Arch. Biochem. Biophys. 2008, 471, 146-158. [CrossRef]

54. Maathuis, F.; Ichida, A.M.; Sanders, D.; Schroeder, J.I. Roles of Higher Plant K+ Channels. Plant Physiol. 1997, 114, 1141-1149. [CrossRef]

55. Shabala, S.; Pottosin, I. Regulation of potassium transport in plants under hostile conditions: Implications for abiotic and biotic stress tolerance. Physiol. Plant. 2014, 151, 257-279. [CrossRef]

56. Barragán, V.; Leidi, E.O.; Andrés, Z.; Rubio, L.; De Luca, A.; Fernández, J.A.; Cubero, B.; Pardo, J.M. Ion Exchangers NHX1 and NHX2 Mediate Active Potassium Uptake into Vacuoles to Regulate Cell Turgor and Stomatal Function in Arabidopsis. Plant Cell 2012, 24, 1127-1142. [CrossRef] [PubMed]

57. Wu, H.; Zhang, X.; Giraldo, J.P.; Shabala, S. It is not all about sodium: Revealing tissue specificity and signalling roles of potassium in plant responses to salt stress. Plant Soil 2018, 431, 1-17. [CrossRef]

58. Santos, E.F.; Mateus, N.S.; Rosário, M.O.; Garcez, T.B.; Mazzafera, P.; Lavres, J. Enhancing potassium content in leaves and stems improves drought tolerance of eucalyptus clones. Physiol. Plant. 2021, 172, 552-563. [CrossRef]

59. Almeida, J.C.R.; Laclau, J.-P.; Gonçalves, J.L.D.M.; Ranger, J.; Saint-André, L. A positive growth response to NaCl applications in Eucalyptus plantations established on K-deficient soils. For. Ecol. Manag. 2010, 259, 1786-1795. [CrossRef]

60. Pulavarty, A.; Kukde, S.; Shinde, V.M.; Sarangi, B.K. Morphological, physiological and biochemical adaptations of Eucalyptus citriodora seedlings under $\mathrm{NaCl}$ stress in hydroponic conditions. Acta Physiol. Plant. 2016, 38, 1-12. [CrossRef]

61. Sun, Z.; Ren, L.; Fan, J.; Li, Q.; Wang, K.; Guo, M.; Wang, L.; Li, J.; Zhang, G.; Yang, Z. Salt response of photosynthetic electron transport system in wheat cultivars with contrasting tolerance. Plant Soil Environ. 2016, 62, 515-521.

62. Corney, H.J.; Sasse, J.M.; Ades, P.K. Assessment of salt tolerance in eucalypts using chlorophyll fluorescence attributes. New For. 2003, 26, 233-246. [CrossRef]

63. Tavakkoli, E.; Fatehi, F.; Coventry, S.; Rengasamy, P.; McDonald, G.K. Additive effects of Na+ and Cl- ions on barley growth under salinity stress. J. Exp. Bot. 2011, 62, 2189-2203. [CrossRef]

64. Morita, M.T.; Shimada, T. The Plant Endomembrane System-A Complex Network Supporting Plant Development and Physiology. Plant Cell Physiol. 2014, 55, 667-671. [CrossRef]

65. Sze, H.; Chanroj, S. Plant Endomembrane Dynamics: Studies of $\mathrm{K}+/ \mathrm{H}+$ Antiporters Provide Insights on the Effects of $\mathrm{pH}$ and Ion Homeostasis. Plant Physiol. 2018, 177, 875-895. [CrossRef]

66. Schumacher, K. pH in the plant endomembrane system-an import and export business. Curr. Opin. Plant Biol. 2014, 22, 71-76. [CrossRef] [PubMed]

67. Ramanjulu, S.; Kaiser, W.; Dietz, K.-J. Salt and Drought Stress Differentially Affect the Accumulation of Extracellular Proteins in Barley. Zeitschrift für Naturforschung C 1999, 54, 337-347. [CrossRef]

68. Mimura, T.; Kura-Hotta, M.; Tsujimura, T.; Ohnishi, M.; Miura, M.; Okazaki, Y.; Mimura, M.; Maeshima, M.; Washitani-Nemoto, S. Rapid increase of vacuolar volume in response to salt stress. Planta 2003, 216, 397-402. [CrossRef] [PubMed]

69. Sharma, S.S.; Yamamoto, K.; Hamaji, K.; Ohnishi, M.; Anegawa, A.; Sharma, S.; Thakur, S.; Kumar, V.; Uemura, T.; Nakano, A.; et al. Cadmium-induced changes in vacuolar aspects of Arabidopsis thaliana. Plant Physiol. Biochem. 2017, 114, 29-37. [CrossRef] [PubMed]

70. Hamaji, K.; Nagira, M.; Yoshida, K.; Ohnishi, M.; Oda, Y.; Uemura, T.; Goh, T.; Sato, M.H.; Morita, M.T.; Tasaka, M.; et al. Dynamic Aspects of Ion Accumulation by Vesicle Traffic Under Salt Stress in Arabidopsis. Plant Cell Physiol. 2009, 50, 2023-2033. [CrossRef]

71. Minic, Z. Physiological roles of plant glycoside hydrolases. Planta 2007, 227, 723-740. [CrossRef]

72. Lum, G.; Min, X.J. Plant Secretomes: Current Status and Future Perspectives; Southern Cross Journals: East Lismore, Australia, 2011; Volume 4, pp. 114-119.

73. Lutts, S.; Kinet, J.; Bouharmont, J. NaCl-induced senescence in leaves of rice (Oryza sativa L.) cultivars differing in salinity resistance. Ann. Bot. 1996, 78, 389-398. [CrossRef]

74. Beadle, C. Growth analysis. In Photosynthesis and Production in a Changing Environment; Springer: Berlin, Germany, 1993; pp. 36-46.

75. Hossain, M.S.; ElSayed, A.I.; Moore, M.; Dietz, K.-J. Redox and reactive oxygen species network in acclimation for salinity tolerance in sugar beet. J. Exp. Bot. 2017, 68, 1283-1298. [CrossRef]

76. Bradford, M.M. A rapid and sensitive method for the quantitation of microgram quantities of protein utilizing the principle of protein-dye binding. Anal. Biochem. 1976, 72, 248-254. [CrossRef]

77. Goldstein, D.B. A method for assay of catalase with the oxygen cathode. Anal. Biochem. 1968, 24, 431-437. [CrossRef]

78. Boller, T.; Kende, H. Hydrolytic enzymes in the central vacuole of plant cells. Plant Physiol. 1979, 63, 1123-1132. [CrossRef] [PubMed] 